Published in final edited form as:

Anal Chem. 2004 April 1; 76(7): 2083-2094. doi:10.1021/ac034971j.

\title{
A Mechanistic Investigation of the Enhanced Cleavage at Histidine in the Gas-Phase Dissociation of Protonated Peptides
}

\author{
George Tsaprailis ${ }^{\dagger, f}$, Hari Nair ${ }^{\dagger,}$, , Wenqing Zhong ${ }^{\dagger, \#}$, Krishnamoorthy Kuppannan ${ }^{\dagger, f}$, Jean \\ H. Futrell ${ }^{\ddagger} \S$, and Vicki H. Wysockit, ${ }^{\text {* }}$ \\ †Department of Chemistry, University of Arizona, P.O. Box 210041, Tucson, AZ 85721-0041 \\ FDepartment of Chemistry, University of Delaware, Newark, DE 19716
}

\begin{abstract}
*Author to whom correspondence should be addressed, vwysocki@email.arizona.edu, Tel: (520) 621-2628, Fax: (520) 621-8407.

\$Current address: Pacific Northwest National Labs, P.O. Box 999 (K8-84), Richland, WA 99352

\#Current address: Wyeth-Ayerst Research, 401 N. Middletown Road, Pearl River, NY 10965

3Current address: Applied Biosystems, 500 Old Connecticut Path, Framingham, MA 01701

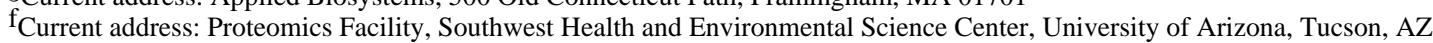
85721

"Supporting Information Available:
\end{abstract}

1. MS/MS spectrum of doubly protonated RVYIHPF obtained by (A) SID at a collision energy of $45 \mathrm{eV}$ on a 2(perfluorooctyl)ethanethiolate $\left[\mathrm{CF}_{3}\left(\mathrm{CF}_{2}\right) \mathrm{CH}_{2} \mathrm{CH}_{2} \mathrm{~S}-\mathrm{Au}\right]$ monolayer surface and $(\mathbf{B})$ low-energy $\mathrm{CID}$ at a $13.0 \%$ relative collision energy; Electrospray ionization.

2. MS/MS spectrum of doubly protonated DRVYIHPF obtained by (A) sustained off-resonance irradiation at an excitation energy of $9 \mathrm{eV}$, (B) SID at a collision energy of $55 \mathrm{eV}$ on a 2-(perfluooctyll)ethanethiolate $\left[\mathrm{CF}_{3}\left(\mathrm{CF}_{2}\right){ }_{7} \mathrm{CH}_{2} \mathrm{CH}_{2} \mathrm{~S}-\mathrm{Au}\right]$ monolayer surface and (C) low-energy CID at a $13.5 \%$ relative collision energy; Electrospray ionization.

3. ESI-LCQ spectrum of $[\mathrm{M}+2 \mathrm{H}]^{2+}$ ions of DRVYIHPFHL (16.0\% relative collision energy).

4. MS/MS spectrum of singly protonated VYIHPF obtained by low-energy CID at a $22.5 \%$ relative collision energy; Electrospray ionization.

5. Electrospray ionization Spectrum of the $[\mathrm{M}+\mathrm{H}]^{+}$ions of AAHAA obtained by SID $(30 \mathrm{eV})$.

6. ESI-LCQ spectrum of $[\mathrm{M}+\mathrm{H}]^{+}$ions of AAAAAHAA ( $22.8 \%$ relative collision energy).

7. MS/MS spectrum of singly protonated RVYIHPF obtained by (A) SID at a collision energy of $60 \mathrm{eV}$ on a 2(perfluorooctyl)ethanethiolate $\left[\mathrm{CF}_{3}\left(\mathrm{CF}_{2}\right){ }_{7} \mathrm{CH}_{2} \mathrm{CH}_{2} \mathrm{~S}-\mathrm{Au}\right]$ monolayer surface and $(\mathbf{B})$ low-energy $\mathrm{CID}$ at a $28.0 \%$ relative collision energy; Electrospray ionization.

8. MS/MS spectrum of singly protonated DRVYIHPF obtained by (A) sustained off-resonance irradiation at an excitation energy of $24 \mathrm{eV}$, (B) SID at a collision energy of $65 \mathrm{eV}$ on a 2-(perfluorooctyl)ethanethiol $\left[\mathrm{CF}_{3}\left(\mathrm{CF}_{2}\right){ }_{7} \mathrm{CH}_{2} \mathrm{CH}_{2} \mathrm{~S}-\mathrm{Au}\right]$ monolayer surface and (C) low-energy CID at a $31.0 \%$ relative collision energy.

9. ESI-LCQ spectrum of $[\mathrm{M}+\mathrm{H}]^{+}$ions of DRVYIHPFHL (37.0\% relative collision energy).

10. MS/MS spectrum of $[\mathrm{M}+2 \mathrm{H}]^{2+}$ ions of RVYIFPF obtained by SID $(20 \mathrm{eV})$, SORI-CID $(10 \mathrm{eV})$ and low-energy CID (8.0 $\%$ relative collision energy).

11. MS/MS spectrum of $[\mathrm{M}+\mathrm{H}]^{+}$ions of VYIFPF obtained by SID (17.5 eV), SORI-CID (11 eV) and low-energy CID (19.0\% relative collision energy).

12. MS/MS spectrum of $[\mathrm{M}+2 \mathrm{H}]^{2+}$ ions of RVYIFAF obtained by SID $(20 \mathrm{eV})$ and low-energy CID ( $8.5 \%$ relative collision energy).

13. MS/MS spectrum of $[\mathrm{M}+\mathrm{H}]^{+}$ions of VYIFAF obtained by SID $(20 \mathrm{eV})$ and low-energy CID $(18.5 \%$ relative collision energy).

14. $\mathrm{MS}^{4}$ by low-energy CID of the $\mathrm{b}_{5}{ }^{2+}$ fragments (RVYIH) produced on $\mathrm{MS}^{3}$ of the $\mathrm{b}_{6}{ }^{2+}$ product (RVYIHA) from the [M $+2 \mathrm{H}]^{2+}$ ions of RVYIHAF. 
Enhanced gas-phase cleavage of peptides adjacent to histidine was investigated. The peptides examined were angiotensins III (RVYIHPF) and IV (VYIHPF) as well as synthetic peptide analogs with altered key residues ((R)VYI-X-Z-F; $\mathbf{X}=\mathrm{F}$ or $\mathrm{H}$ and $\mathbf{Z}=\mathrm{A}, \mathrm{P}$ or Sar) or a fixed charge $\Phi_{\mathbf{3}} \mathbf{P}^{\mathbf{+}} \mathbf{C H}_{\mathbf{2}} \mathbf{C}(\mathbf{O})$-VYIHPF. While all singly protonated peptide ions containing both histidine and arginine fragment non-selectively, the doubly protonated peptide ions with arginine and histidine, and the singly protonated peptides containing histidine but not arginine, cleave in a selective manner. In particular, dominant complementary $\mathrm{b}^{+} / \mathrm{y}^{+}$product ions resulting from cleavage between the HP amide bond are observed. For the fixed-charge derivative, selective cleavage occurs only if a proton is added to produce a doubly charged precursor. The results are consistent with involvement of a protonated histidine in the selective cleavage. The ratio of $\mathrm{b}^{+} / \mathrm{y}^{+}$is determined by the identity of the residue $\mathrm{C}$-terminal to histidine and by the ability of protonated histidine to transfer a proton to the $\mathrm{C}$-terminal leaving fragment. This was probed further by systematically changing the residue $\mathrm{C}$-terminal to histidine and by alkylating histidine. The results indicate that while $\mathrm{b}^{+} / \mathrm{y}^{+}$complementary ion pairs dominate in doubly protonated RVYIHPF, $\mathrm{b}_{5}{ }^{2+}$ and $b_{6}{ }^{2+}$ product ions dominate the spectra of doubly protonated RVYIHAF. Also, dominant $b_{5}{ }^{2+}$ product ions are observed when the histidine side chain is alkylated $\left(\mathrm{H}^{*}\right)$ in doubly protonated RVYIH*PF. Based on all of the results, a selective fragmentation mechanism for enhanced cleavage at histidine involving an atypical $b$ ion structure is proposed.

\section{Introduction}

Proteomics and related biosciences rely on mass spectrometry and tandem mass spectrometry (MS/MS) for peptide sequencing and protein identification. ${ }^{1,2}$ Moreover, obtaining structural information by MS/MS, especially for proteins and peptides, is of paramount importance in this "post-genome" era in which characterization of proteins is a necessary step in understanding gene function. To meet this goal, computer algorithms now exist for correlating peptide MS/MS spectra with theoretical MS/MS spectra (or predicted fragmentation spectra), generated from sequence strings in various protein and translated nucleotide databases. ${ }^{3-7}$ While such computer programs are proving highly useful for peptide sequence determination and/or protein identification following LC-MS/MS, ${ }^{8}, 9$ their utility might be improved if our basic knowledge of peptide dissociation mechanisms and energetics could be increased. Current algorithms perform this identification with little or no priori insight into what rules (either general or specific) govern peptide dissociation. Hence, false positive correlation scores can be obtained between theoretical and experimental MS/MS spectra of peptides. As a consequence, protein identification using this MS/MS approach can be wrong. Thus, incorporation of robust peptide fragmentation rules to these computer algorithms, through fundamental and applied research on peptide dissociation, may be beneficial.

In MS/MS of peptides, fragment ions result from cleavages along the peptide backbone ${ }^{10}$ and/or at the various amino acid side chains. Cleavage of the amide bond with retention of the charge on the $\mathrm{C}$-terminal peptide fragment results in $\mathrm{y}_{n}$ ions, whereas if the charge is retained on the N-terminal side, $\mathrm{b}_{n}$ ions are generated. ${ }^{11-13}$ Ions $28 \mathrm{u}$ lower in mass than $\mathrm{b}_{n}$ fragment ions are designated $\mathrm{a}_{n}$ ions. Immonium ions produced from various amino acids present in the peptides, as well as ions that correspond formally to the loss of $\mathrm{H}_{2} \mathrm{O}\left(\mathrm{b}_{\mathrm{n}}{ }^{\circ}\right.$ or 
$\left.\mathrm{y}_{\mathrm{n}}{ }^{\circ}\right)$ and/or $\mathrm{NH}_{3}\left(\mathrm{~b}_{\mathrm{n}}{ }^{*}\right.$ or $\left.\mathrm{y}_{\mathrm{n}}{ }^{*}\right)$ from $\mathrm{y}$ or $\mathrm{b}$ fragment ions, are also present in MS/MS spectra of protonated peptides. ${ }^{14-17}$ The mobile proton model ${ }^{8,13-16,18,19}$ has been employed to rationalize selective and non-selective fragmentation in protonated peptides; strongly basic residues such as arginine are expected to sequester the ionizing proton, ${ }^{20}$ and have been associated with higher energy requirements for fragmentation. ${ }^{21}$

Peptides, although polymeric in nature, offer many challenges for sequencing in the gas phase because fragmentation is not always general or non-selective. Many factors can influence peptide dissociation in the gas phase including the nature of the residues present (neutral vs. acidic vs. basic), ${ }^{21-23}$ the charge state of the precursor ion, ${ }^{21,24}$ the composition of the peptide backbone (amide vs. N-alkylated), ${ }^{25,} 26$ the size ${ }^{27}$ and the conformation of the peptide. ${ }^{18,28-33}$ In some instances some of these factors can lead to enhanced or specific cleavages at certain peptide bonds, limiting the information obtained from the MS/MS spectrum. As an example, it has recently been shown that selective cleavages dominate the MS/MS spectra of peptides with arginine and acidic residues. ${ }^{23,34-36}$ Selective cleavages at acidic residues dominate the MS/MS spectra of these peptides if the number of ionizing protons does not exceed the number of arginine residues. Similar selective cleavage (Cterminal to acidic residues) has also been observed on statistical analysis of a CID spectral database of doubly charged peptides with histidine, arginine and acidic residues. ${ }^{37}$ Alternatively, non-selective cleavages occur over the peptide backbone in the presence of a mobile proton (a proton in excess of the number of basic residues in the peptide). In support of the utility of this fragmentation rule, and in spite of the fact that it was developed and tested for peptides, the work of Stephenson et $a l .{ }^{38}$ shows that $[\mathrm{M}+11 \mathrm{H}]^{11+}$ ions of lysozyme, a $14.3 \mathrm{kDa}$ polypeptide that contains 11 arginine residues, fragment predominantly between Asp48-Gly49 and Asp18-Asn19 resulting in two complementary pairs of product ions. The $[\mathrm{M}+14 \mathrm{H}]^{14+}$ precursor ions of lysozyme, however, fragment nonselectively, consistent with the fact that the number of protons added is greater than the number of arginine residues available to sequester protons.

In this study, we attempt to gain a better understanding of the propensity of certain peptides to be ionized at a specific basic residue, histidine, and investigate the influence of this protonation on selective cleavage at histidine. Recently, data mining of a set of peptide spectra has shown that histidine is the amino acid residue most likely to show preferential cleavage at its C-terminal side in doubly-protonated tryptic peptides (when histidine is likely to be protonated at its side chain rather than $\mathrm{N}$-terminal). ${ }^{39}$ In the research described below, enhanced cleavage at histidine is demonstrated for singly and doubly protonated model peptides using a variety of activation methods that deposit different internal energy distributions and access different time frames for dissociation. The dependence of selective cleavages at histidine on the nature of the residue $\mathrm{C}$-terminal to histidine was tested by systematic residue substitutions from Pro to Sar to Ala. This is especially important because proline is another amino acid residue that directs selective cleavage of the peptide backbone. Either complementary $\mathrm{b}^{+} / \mathrm{y}^{+}$product ions or $\mathrm{b}^{2+}$ product ions at histidine are produced depending on the nature of the residue $\mathrm{C}$-terminal to histidine. Moreover, a plausible formation mechanism common to both these types of product ions is proposed. Finally, MS/MS/MS and resonance ejection experiments provide data that support a unique histidine 
$\mathrm{b}$ ion structure. A brief summary of this work was presented in an article highlighting the role of mobile protons in peptide fragmentation ${ }^{40}$ the present paper provides the data and analysis that support the proposed mechanism and structure. A related computational study on $\mathrm{b}$ ion structure involving Histidine has been published. ${ }^{41}$

\section{Experimental Section}

\section{Peptide Synthesis}

Angiotensin III (RVYIHPF), and Angiotensin IV(VYIHPF) were purchased from Sigma (St. Louis, MO) as the acetate salts and used without any further purification. Iodoacetic anhydride and tris(2,4,6-trimethoxyphenyl)phosphine were also purchased from Sigma. Any synthetic peptides required were prepared by solid-phase synthesis protocols outlined by Atherton and Sheppard. ${ }^{42}$ 9-Fluoroenylmethoxycarbonyl (Fmoc) derivatives of the various amino acids required ( $\mathrm{N}^{\mathrm{a}}$-Fmoc- $\mathrm{N}^{\mathrm{g}}$-2,2,5,7,8-pentamethylchroman-6-sulfonyl-L-arginine; Fmoc-L-valine; Fmoc-O-t-butyl-L-tyrosine; $\mathrm{N}^{\mathrm{a}}$-Fmoc-N ${ }^{\text {im }}$-trityl-L-histidine; Fmoc-Lalanine monohydrate; Fmoc-L-phenylalanine; Fmoc-L-proline) were purchased from Advanced Chemtech (Louisville, KY) with the exception of Na-Fmoc-im-benzyl-Lhistidine $\left(\mathrm{H}^{*}\right)$ which was purchased from Sigma. The C-terminal residues required for peptide synthesis were purchased already attached to resins from Calbiochem/Novabiochem (San Diego, CA) as was sarcosine [denoted as Sar; $\mathrm{N}^{\mathrm{a}}$-Fmoc-L-sarcosine (Nmethylglycine)]. All other reagents required during synthesis were from Aldrich (Milwaukee, WI). Deprotection was performed by using piperidine (50\%) in dimethylformamide (DMF). Coupling reactions between successive L-amino acid residues was performed in a solution of DMF containing a 2-4 fold excess of $\mathrm{N}$ hydroxybenzotriazole dihydrate (HOBt), benzotriazole-1-yl-oxy-tris-(dimethyamino)phosphonium hexafluorophosphate (BOP; Castro's reagent), diisopropylethylamine (DIEA), and the appropriate Fmoc-protected amino acid. The synthesized peptides were removed from the resin and deprotected using a mixture of 95\% trifluoroacetic acid (TFA), 2.5\% $\mathrm{H}_{2} \mathrm{O}$ and $2.5 \%$ 1,2-ethanedithiol (EDT) for $1.5 \mathrm{~h}$ at ambient temperature. In the case of RVYIH*PF, deprotection and cleavage from the resin was carried out for $1 \mathrm{~h}$ because the alkyl group is stable under these conditions. ${ }^{43}$ Once each synthetic peptide was precipitated in diethyl ether, its purity and identity were checked by mass spectrometry. For the fixedcharge derivative of peptide VYIHPF, the resin-bound peptide $(0.011 \mathrm{mmol})$ with the free $\mathrm{N}$-terminus was reacted with $3 \mathrm{x}$ molar excess iodoacetic anhydride in anhydrous DMF for 30 min, washed with DMF twice, and then reacted with $4 \mathrm{x}$ molar excess tris $(2,4,6-$ trimethoxyphenyl)phosphine in toluene/DMF $(1: 1 \mathrm{v} / \mathrm{v})$ for $90 \mathrm{~min}$. The resin-bound fixedcharge VYIHPF derivative (i.e., $\Phi_{3} \mathrm{P}^{+} \mathrm{CH}_{2} \mathrm{C}(\mathrm{O})$-VYIHPF), was then washed with toluene, $\mathrm{DMF}$, and then finally with dicholoromethane (DCM). Cleavage from the resin and peptide isolation were carried out as described above.

\section{Surface-Induced Dissociation}

The instrument used for the SID experiments is a custom-built tandem quadrupole mass spectrometer $\left(\mathrm{Q}_{1} \mathrm{Q}_{2}\right)$ specifically designed for low-energy ion-surface collisions. It has been described previously in greater detail. ${ }^{19,21,44}$ The singly- and doubly protonated peptides were formed by electrospray ionization using a heated capillary electrospray design based 
on those of Chowdhury et al. ${ }^{45}$ and Papac et al. ${ }^{46}$ Peptide analytes were dissolved in a $70 / 30 \%(\mathrm{v} / \mathrm{v})$ mixture of methanol/ $\mathrm{H}_{2} \mathrm{O}$ containing $1 \%$ acetic acid to give the appropriate concentration $(\sim 30-50 \mathrm{pmol} / \mu \mathrm{L})^{21}$, and sprayed at atmospheric pressure from a syringe needle (Syringe pump: Sage ATI Orion Model 361) held at 4.2-4.7 kV (flow rate of $2 \mu \mathrm{L} /$ $\mathrm{min})$, towards a metal capillary $(120 \mathrm{~V})$. The temperature of the metal capillary was maintained at $120 \mathrm{oC}$ to ensure proper desolvation of the ions. The desolvated ions were directed toward a skimmer cone $(90 \mathrm{~V})$, after which they entered into the high-vacuum region of the mass spectrometer, where they were analyzed and detected. SID was accomplished by changing the potential difference between the ion source skimmer cone and the surface; for multiply protonated peptide ions the potential difference is multiplied by the number of charges to calculate the ion kinetic energy.

The chemically modified surfaces used in the SID experiments were self-assembled monolayer films of 2-(perfluorooctyl)ethanethiol $\left[\mathrm{CF}_{3}\left(\mathrm{CF}_{2}\right)_{7} \mathrm{CH}_{2} \mathrm{CH}_{2} \mathrm{~S}\right.$-Au, referred to as FC10 SAM] or 2-(perfluorodecyl)ethanethiol $\left[\mathrm{CF}_{3}\left(\mathrm{CF}_{2}\right)_{9} \mathrm{CH}_{2} \mathrm{CH}_{2} \mathrm{~S}\right.$-Au, referred to as $\mathrm{FC} 12$

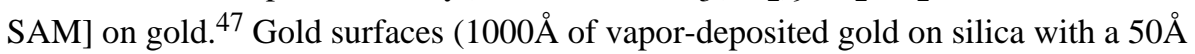
adhesion layer of titanium between the silica and the gold) were obtained from Evaporated Metal Films (Ithaca, NY) and cleaned by using a UV cleaner (UV-Clean, Boekel, Philadelphia, PA) before immersion into the alkanethiol solution ( $1 \mathrm{mM}$ in ethanol, $24 \mathrm{hr}$ ) as previously described. ${ }^{21}$

\section{Sustained Off-Resonance Irradiation}

A Bruker 7-tesla Fourier transform mass spectrometer (FTICR-MS) ${ }^{48}$ combined with an Analytica electrospray ionization source was also used for MS/MS studies. The peptide solutions $(5 \mu \mathrm{M})$, were electrosprayed $(4 \mathrm{kV})$ into the vacuum system at a flow rate of 0.5 $\mu \mathrm{L} / \mathrm{min}$ using a Harvard Apparatus syringe pump. A glass capillary coated with metal on both ends transfers the ions from atmospheric pressure into the vacuum system. Desolvation of the sample was achieved by heating the capillary with counterflow $\mathrm{N}_{2}$ gas at $200^{\circ} \mathrm{C}$. The CID activation method employed was sustained off-resonance irradiation (SORI), ${ }^{49}$ a slow multi-step activation process in which ion dissociation processes that occur in the several msec to sec time scale can be observed. The collision gas pulsed into the ion cyclotron resonance (ICR) cell was $\mathrm{CO}_{2}$. For the SORI-CID experiments, the radio frequency (RF) irradiation was offset by $700 \mathrm{~Hz}$ above or below the resonance frequency of the selected ions. ${ }^{49,50}$ For the resonance ejection experiments, doubly protonated RVYIHAF produced in the external ESI source was isolated by using correlated sweep and then excited at its cyclotron frequency to a certain kinetic energy. The product ions of interest produced during the activation (i.e., $\mathrm{b}_{6}{ }^{2+}$ ) were ejected out of the cell by applying a resonant ejection pulse (1s) in order to prevent their further dissociation. In this manner, further fragmentation of the $\mathrm{b}_{6}{ }^{2+}$ product ions in the cell does not occur (unless the fragmentation is faster than the minimum time required for ejection) and only fragment ions (other than the ejected ions) originating from the precursor ions are observed.

\section{Low-Energy Collision-Induced Dissociation}

Low-energy CID experiments were performed with a Finnigan LCQ ion trap mass spectrometer (San Jose, CA). The peptides were dissolved in a solution of $\mathrm{H}_{2} \mathrm{O}: \mathrm{MeOH}(1: 1$; 
$\mathrm{v} / \mathrm{v}$ ) containing $1 \%$ acetic acid to make up a concentration of $20-30 \mathrm{pmol} / \mu \mathrm{L}$. The peptide solutions were then sprayed into the mass spectrometer at a rate of $3 \mu \mathrm{L} / \mathrm{min}$. The applied needle voltage used was $4.8 \mathrm{kV}$ and the capillary temperature was maintained at $200^{\circ} \mathrm{C}$ for all samples. Unit mass selection of the precursor ion was performed in order to avoid ambiguities from isotope contributions. The excitation energy (indicated as \% collision energy by the manufacturer), was incremented in small steps to selectively monitor low energy fragmentation processes for the precursor ions selected. For MS/MS/MS, desired fragment ions produced from the precursor (MS/MS) were selected and isolated in the trap and then excited as described above. Energy resolved mass spectral "breakdown" curves were accomplished by selecting the product ion of interest in the ion trap and performing MS/MS/MS at incremented energy steps (\% relative collision energies as referenced by the manufacturer). The percent relative abundance of the fragment ions following MS/MS/MS were plotted as a function of energy.

\section{Molecular Modeling}

The peptides RVYIHPF and RVYIHAF were built in Macromodel ${ }^{51}$ (Version 6.0) using the program's amino acid library. They were then modified to carry two positive charges with the charges being placed on the arginine and histidine residue side chains. As either of the two nitrogens ( $\tau-$ and $\pi$-) on the side chain of histidine can carry the ionizing proton, each nitrogen atom was sequentially protonated such that two versions of doubly protonated RVYIHPF and RVYIHAF were modeled. The built-in protonated peptide structures were first subjected to 500 optimization iterations in Macromodel resulting in an energetically refined starting structure. Stochastic molecular dynamics using the AMBER force field ${ }^{52}$ were then performed on each of these structures using the Batchmin program of Macromodel. AMBER force field default parameters were used for the electrostatic and hydrogen bonding treatments during the molecular dynamics. Moreover, large distance cut off values were assigned to ensure smoother convergence and the Polak-Riviere Conjugate Gradient (RPCG) ${ }^{53}$ was used for the program's energy minimization routines. In all, 10000 structures were sampled during the stochastic dynamics run ( $1 \mathrm{fs}$ time step; $10000 \mathrm{ps}$ total time; $800 \mathrm{~K}$ initial and final temperature; $0.5 \mathrm{ps}$ bath time). Our choice of temperature for the molecular dynamics was based on previous analysis of kinetic energy transfer into internal energy for singly protonated YGGFL using thermal decomposition kinetics methods. ${ }^{54}$ Those results showed that applying the thermal kinetic parameters to the dissociation rate constant for singly protonated YGGFL at the inflection point of the SID fragmentation efficiency curve yields an effective temperature of $800 \mathrm{~K}$.

\section{Results and Discussion}

\section{Gas-Phase Dissociation of Angiotensin III (RVYIHPF) and IV (VYIHPF)}

(A) Selective Fragmentation in Doubly Protonated RVYIHPF-Figure 1 shows the MS/MS spectra of doubly protonated RVYIHPF under SORI-CID conditions. Selective fragmentation is observed for RVYIHPF with $y_{2}$ and $b_{5}$ as the dominant product ions. These product ions are the result of cleavage at the HP amide bond. This selective cleavage is most clearly represented in the SORI-CID spectrum of RVYIHPF (Figure 1). SID and low-energy CID also show this cleavage, although to a less striking extent. The $a_{5}, b_{4} / a_{4}$ and $b_{3} / a_{3}$ ions 
produced by SID (supplementary figure 1A) are likely the result of further fragmentation of the $b_{5}$ product ion, which supports an enhanced cleavage at the HP bond. It is common to see pairs of $\mathrm{b}$ and $\mathrm{a}$ ions produced by SID. The quadrupole ion trap instrument which discriminates against low mass ions of $\mathrm{m} / \mathrm{z}$ below $35 \%$ of the parent mass, ${ }^{55}$ is responsible for the low abundance of the $y_{2}$ product ion in the low-energy CID spectrum (supplementary figure 1B). Strong complementary $b_{6} / y_{2}$ and $b_{6} / y_{4}$ ions were also observed in the SORI-CID spectra of doubly protonated angiotensin II (DRVYIHPF) and low-energy CID spectra of doubly protonated angiotensin I (DRVYIHPFHL), respectively (supplementary figures $2 \&$ $3)$.

Selective cleavage C-terminal to histidine as seen here (Figure 1), has been previously observed under CID conditions with an ESI double focusing sector instrument by $\mathrm{Hu}$ and Loo for $\mathrm{Ni}^{2+}, \mathrm{Co}^{2+}$, and $\mathrm{Zn}^{2+}$ complexes of peptides. ${ }^{56}$ Moreover, dominant $\mathrm{b}^{+} / \mathrm{y}^{+}$product ion pairs ( $b_{6} / y_{2}$ in DRVYIHPF and $b_{5} / y_{2}$ in RVYIHPF) have also been documented by Adams et al. and Sullards et al. ${ }^{57,58}$ who measured the kinetic energy release of the $\mathrm{b}_{5}$ and $\mathrm{y}_{2}$ ions and concluded that these were complementary ions resulting from cleavage at the HP amide bond in doubly protonated RVYIHPF. These authors however, stated that it is not clear whether the fragmentation is charge-directed or charge-remote. The work of Tang and Boyd also supports the direct dissociation to complementary $\mathrm{b}^{+} / \mathrm{y}^{+}$product ions from doubly protonated ions of tryptic peptides. ${ }^{59}$

(B) Selective Cleavage in Singly Protonated VYIHPF-Figure 2 shows the MS/MS spectra of singly protonated VYIHPF under SORI-CID and SID conditions (see supplementary figure 4 for ion-trap CID spectrum). Once again, selective cleavage at the HP amide bond is seen leading to either $a b_{4}$ or, in SID, also a y2 product ion. Differences in the time frame of the dissociation event and the energy imparted to the ion during the collision contribute to the differences seen in the spectra (compare Figures 2A and 2B). Because singly protonated VYIHPF does not contain a highly basic arginine to sequester the ionizing proton, these results suggest that the single ionizing proton, likely located on the basic side chain of His ${ }^{60,61}$ is promoting the selective cleavage at the HP amide bond, consistent with the selective cleavage that occurs for peptides containing arginine, histidine and two ionizing protons (Figure 1). Upon dissociation, if the charge is retained on the $\mathrm{N}$-terminal fragment, a b-type ion results (i.e., $b_{4}$ ), while if the charge is retained on the C-terminal fragment, a y-type ion (i.e., $\mathrm{y}_{2}$ ) is formed. Singly protonated AAHAA and AAAAAHAA were also dissociated by SID and low-energy CID (supplementary figures $5 \& 6$ ). The MS/MS results reveal that abundant product ions are produced that correspond to cleavage $\mathrm{C}$-terminal to histidine ( $\mathrm{b}_{3}$ and $\mathrm{b}_{6}$, respectively), although other product ions, including a strong $b_{m-1}(m=$ total number of residues), are also detected.

(C) Non-selective Fragmentation in Singly Protonated RVYIHPF-Figure 3 shows the SORI-CID MS/MS spectrum of singly protonated RVYIHPF (see supplementary figure 7 for SID and ion-trap CID spectra). It is apparent from a comparison of this spectrum (Figure $3 ; 34 \mathrm{eV}$ excitation energy) with that for the doubly protonated peptide (Figure 1; $6 \mathrm{eV}$ excitation energy), that singly protonated RVYIHPF ions require higher energies for the fragmentation process (as predicted by the mobile proton model for a peptide with one 
arginine and one proton ${ }^{21}$ ) and fragment to produce a number of sequence ions across the mass range. Fragment ions that differ from $b$ and a ions by the formal loss of ammonia ${ }^{15}$ are also abundant in the spectrum (designated by *). Previous work by Starrett and DiDonato ${ }^{62}$ using collision induced dissociation in a reversed-geometry double-focusing mass spectrometer has also demonstrated non-selective fragmentation seen here for singly protonated angiotensin II (DRVYIHPF) (supplementary figure 8 and 9).

(D) Non-selective Fragmentation in $\Phi_{3} \mathrm{P}+\mathrm{CH}_{2} \mathrm{C}(\mathrm{O})$-VYIHPF and Selective Fragmentation in $\left[\Phi_{3} \mathrm{P}^{+} \mathrm{CH}_{2} \mathrm{C}(\mathrm{O}) \text {-VYIHPF }+\mathrm{H}^{+}\right]^{2+}-\mathrm{As}$ described above, the addition of two protons to RVYIHPF with subsequent activated dissociation results in selective cleavage of the HP amide bond while addition of only one proton gives non-selective fragmentation. A fixed charge [i.e., tris(2,4,6-trimethoxy phenyl)phosphine)] was placed at the N-terminus of VYIHPF to mimic the protonated arginine in RVYIHPF (i.e., to provide charge that is not mobile, that doesn't readily intramolecularly transfer to another basic site). The fragmentation of this fixed-charge derivative was evaluated in the absence and presence of an ionizing proton. Figure 4A shows the low-energy (ion trap) CID spectrum of $\Phi_{3} \mathrm{P}^{+} \mathrm{CH}_{2} \mathrm{C}(\mathrm{O})$-VYIHPF and as expected, the fragmentation is non-selective. Selective fragmentation at the HP amide bond, which mirrors that seen with doubly protonated RVYIHPF, is observed when a proton is added to this fixed-charge peptide derivative $\left(\Phi_{3} \mathrm{P}^{+} \mathrm{CH}_{2} \mathrm{C}(\mathrm{O})-\mathrm{VYIHPF}+\mathrm{H}^{+} ;\right.$Figure $\left.4 \mathrm{~B}\right)$. The data suggest that protonation at the histidine side chain by an available proton directs this selective cleavage.

\section{Histidine b ion Formation and Structure}

In general, the combined mass spectral results presented above indicate that the addition of a second ionizing proton to angiotensin III (RVYIHPF) has a significant effect on the fragmentation pattern with the doubly protonated peptides dissociating in a selective manner. This is in contrast to peptides containing a single Arg and no His, whose doubly protonated precursor ions exhibit non-selective cleavage at the various amide bonds. ${ }^{11,15,19,21,22,34,63}$ Because it is well established that a highly basic arginine side chain will sequester one of the ionizing protons in the doubly protonated peptide ions formed by ESI, ${ }^{21,} 22$ it follows that the location of the second ionizing proton is important in directing the selective cleavages $\mathrm{C}$-terminal to histidine in the peptides under investigation here.

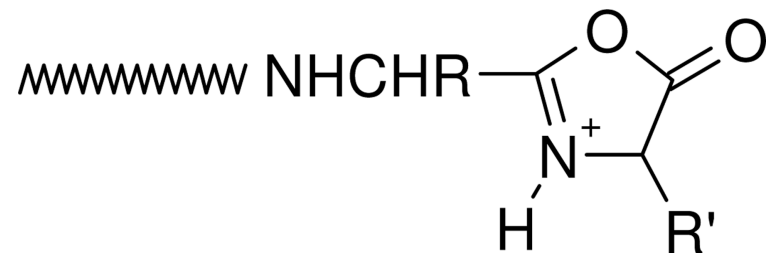




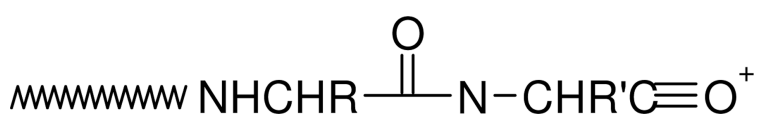

The nature (including the formation and structure) of typical charge-directed $\mathrm{b}$ ions in protonated peptides has been studied extensively in the past. ${ }^{26,}{ }^{63-69}$ Both protonated oxazolone (1) ${ }^{26,63-67}$ and acylium (2) ${ }^{68,69}$ structures have been proposed as the structures of $\mathrm{b}$ ions, with compelling evidence given for both. Alternatively, an equilibrium might exist in the gas-phase between these two different $b$ ion structures which would bring harmony to all the different types of experimental evidence. The experimental MS/MS data in Figures 1 and 2 prompts the question of whether the dominant $b$ ions at histidine might be oxazolone, acylium or "other" in structure. The side chain of histidine is known to be basic and a potential site of protonation in peptides. ${ }^{60,61} \mathrm{With}$ this in mind, we propose the mechanism depicted in Scheme 1 to account for histidine $b$ ion formation in singly protonated VYIHPF. As shown in Scheme 1, following protonation at the side chain of histidine, one proton is transferred intramolecularly from the histidine imidazole to the histidine carbonyl oxygen. This results in an electropositive histidine carbonyl carbon which can be attacked by the nucleophilic imino nitrogen of histidine resulting in a fused bicyclic 5-membered ring structure. Next, a 1-3 hydrogen shift or a more complicated intramolecular atom shuttling induces cleavage. ${ }^{59,68-72}$ The result is a unique protonated histidine $\mathrm{b}$ ion and a neutral Cterminal leaving piece (Scheme 1). Alternatively, the proton could initially be transferred from the histidine imidazole to the amide- $\mathrm{N}$ of the His-Pro bond; the question of involvement of protonated amide carbonyl oxygen vs nitrogen has not been definitively answered. $40,73,74$ To produce the $\mathrm{b}^{+} / \mathrm{y}^{+}$pair from a doubly protonated peptide, a proton transfer to the $\mathrm{C}$-terminal leaving piece is required as discussed below. For a peptide containing arginine to which a single proton is added, (e.g., RVYIHPF) arginine is expected to sequester the single ionizing proton. ${ }^{21,22}$ Following activation of singly protonated RVYIHPF, the proton is immobile ${ }^{15}, 16,19,21,22,63,75-77$ to a great extent, leading to initial loss of ammonia. Further fragmentation occurs by charge-remote fragmentation or fragmentation initiated by a high energy proton transfer that does not favor transfer to any one particular site. As a result the fragmentation is non-selective (Figure 3). However, upon addition of the second ionizing proton which is expected to reside (at least initially) at the side chain of histidine, the fragmentation becomes selective. In this case, $a b^{+} / y^{+}$ complementary ion pair results (Figure 1).

\section{Enhanced Cleavage at Histidine For Different His-Xxx Bonds}

Proline, due to its cyclic nature and alkylated nitrogen, has long been recognized to direct cleavage $\mathrm{N}$-terminal to this residue resulting in dominant y-type fragment ion formation. ${ }^{78-80}$ Indeed, the MS/MS spectra of doubly protonated peptides with no His, RVYIFPF and singly protonated VYIFPF, demonstrate dominant $b_{5} / y_{2}$ and $b_{4}$ product ions, respectively, while those of doubly protonated RVYIFAF and singly protonated VYIFAF ions show non-selective fragmentation (supplementary figures 10-13). This suggests that it is not the histidine alone that is responsible for the enhanced HP cleavage in doubly 
protonated RVYIHPF. To ascertain if enhanced cleavage at histidine persists irrespective of its C-terminal residue, proline was substituted by sarcosine (Sar; N-methylglycine) and then by alanine. Sar contains an alkylated nitrogen mimicking the alkylation of Pro while Ala does not contain an alkylated nitrogen. The MS/MS spectra of doubly protonated RVYIHPF, RVYIHSarF and RVYIHAF ions obtained under SORI-CID conditions are shown in Figure 5A,B,C. It is evident from the mass spectral data that while complementary $\mathrm{b}_{5} / \mathrm{y}_{2}$ product ions dominate the spectrum of RVYIHPF (Figure $5 \mathrm{~A}$ ), $\mathrm{b}_{5}{ }^{2+}$ and $\mathrm{b}_{6}{ }^{2+}$ product ions become more significant on substitution of Pro by Ala (Figure 5C). The spectrum of doubly protonated RVYIHSarF (Figure 5B) is intermediate to those of the other two peptides, with complementary $\mathrm{b}_{5}{ }^{+} / \mathrm{y}_{2}{ }^{+}$product ions in comparable abundance to $\mathrm{b}_{6}{ }^{2+}$ product ions. The ratio of complementary $\mathrm{b}^{+} / \mathrm{y}^{+}$product ions to doubly charged $\mathrm{b}$ product ions in RVYIHPF and RVYIHSarF (Figure 5) suggests that the cyclic nature of Pro and the conformation it induces in RVYIHPF are more important in aiding complementary $\mathrm{b}^{+} / \mathrm{y}^{+}$ product ion formation than an alkylated nitrogen because alternate low-energy fragmentation pathways begin to compete following the Pro $\rightarrow$ Sar substitution. A commonality in the MS/MS spectra of the current peptides (Figure 5) is dominant cleavage $\mathrm{C}$-terminal to the histidine residue resulting in sequence-dependent selective product ions (i.e., dominant complementary $b_{5}{ }^{+} / y_{2}{ }^{+}$product ions in RVYIHPF and dominant $b_{5}{ }^{2+}$ and $\mathrm{b}_{6}{ }^{2+}$ product ions in RVYIHAF). Recently, it has been shown by statistical analysis of doubly charged tryptic peptides that histidine leads to preferential cleavage on its C-terminal side in $\mathrm{b}$ ion formation. ${ }^{39} \mathrm{~A}$ mechanism which accounts for the formation of doubly charged b-type product ions C-terminal to histidine in RVYIHAF is discussed below.

\section{A Common Intermediate in the Production of Selective $b^{2+}$ or $b^{+} / \mathbf{y}^{+}$Complementary Product lons at Histidine Residues}

The mass spectral data presented above (Figures 1,2 and 5) as well as previous work by Adams et al. and Sullards et al. ${ }^{57,58}$ suggest that histidine is a very likely protonation site in the peptides under investigation. A means must exist by which the doubly protonated precursor ions of RVYIHPF, protonated at both the side chains of Arg and histidine, dissociate to give complementary $\mathrm{b}^{+} / \mathrm{y}^{+}$product ions. Moreover, while dominant complementary $\mathrm{b}^{+} / \mathrm{y}^{+}$product ions are produced for His-Pro cleavage, $\mathrm{b}_{5}{ }^{2+}$ product ions dominate in RVYIHAF. Following the postulate that the ionizing proton resides on the side chain of histidine in singly protonated VYIHPF (see Section II; $b_{4}$ product ion formation), we propose a common mechanism, presented in Scheme 2, which demonstrates the formation of $b_{5}{ }^{2+}$ or $b_{5}{ }^{+} / y_{2}{ }^{+}$product ions. Following initial protonation at the two most basic sites in the peptide (arginine and histidine side chains), ${ }^{57,80,81}$ one proton is transferred intramolecularly from the histidine side chain $\pi$-nitrogen to the histidine carbonyl oxygen (see Scheme 1). This starting peptide ion structure is supported by our molecular dynamics calculations which reveal that this particular proton bridge (within 2.5 $\AA$ ) occurs in $\sim 30 \%$ and $\sim 21 \%$ of the 10000 structures of RVYIHPF and RVYIHAF sampled, respectively. It is of interest that a similar proton bridge from an ionizing proton on the histidine side chain $\tau$-nitrogen, to the histidine carbonyl oxygen, is not supported by the modeling results clearly implying that initial proton transfer must occur from the ionized $\pi$ nitrogen of histidine. Nucleophilic attack by the imino (i.e., $\pi$-) nitrogen of histidine on the now electropositive carbonyl carbon results in the fused bicyclic 5-membered ring structure 
involving the histidine side chain (Scheme 2). The molecular modeling results showed that in this closed-ring doubly protonated RVYIHPF peptide structure (top structure, Scheme 2), the transferred proton is now within H-bonding distance to the Pro backbone nitrogen in one third (i.e. 29\%) of 10000 structures sampled. A similar hydrogen bonding interaction is seen in $\sim 80 \%$ of 10000 sampled structures of RVYIHAF. During this proton transfer step, the amide bond between HP or HA is weakened and is cleaved. This results in a complex intermediate where the formally separated product species might be in close proximity to each other, either via hydrogen bonds or electrostatic interactions in an ion-molecule complex. At this step, a branching point in the fragmentation can occur. Namely, in the case of RVYIHPF, it is proposed that a proton transfer takes place from the protonated histidine side chain to the basic amine nitrogen of Pro within the complex intermediate, leading to simultaneous formation of the $\mathrm{b}_{5}{ }^{+} / \mathrm{y}_{2}{ }^{+}$product ions. In contrast to RVYIHPF where a second hydrogen is also transferred to the $\mathrm{C}$-terminal fragment $(\mathrm{PF})$ from the $\tau$-nitrogen of histidine to result in $\mathrm{y}_{2}$ product ion formation (Figures $1 \mathrm{~A}$ and $5 \mathrm{~A}$ ), no final proton transfer step takes place from $[\mathrm{RVYIH}+2 \mathrm{H}]^{2+}$ to the departing AF (Figure 5C). This leaves both protons on the $\mathrm{N}$-terminal fragment resulting in the $\mathrm{b}_{5}{ }^{2+}$ product ion and a neutral $\mathrm{C}$-terminal fragment.

It has recently been reported by Nold et al. ${ }^{82}$ that during dissociation in protonated peptides, competition exists for the added proton between the $\mathrm{N}$ - and $\mathrm{C}$-terminal fragments. This competition is based on the proton affinities of the two segments. Typically, $\mathrm{N}$-terminal fragments with cyclic (or oxazolone like) ${ }^{63-65,83,84}$ structures and C-terminal fragments with linear structures ${ }^{83,85}$ are produced on peptide dissociation. From this it follows that the relative basicity of the two penultimate amino acid segments ( $\mathrm{PF}$ and $\mathrm{AF}$ ), must also play a role in the transfer of the added proton from histidine that leads to a charged (i.e., $\mathrm{y}_{2}$ ) and/or neutral linear C-terminal fragment with concomitant $b_{5}{ }^{+}{ }_{\text {or }} b_{5}{ }^{2+}$ product ion formation, respectively. Indeed the side chain of alanine is less basic than that of proline and therefore less likely to promote proton transfer, consistent with the observed intensities of the $\mathrm{b}_{5}{ }^{+}$and $\mathrm{b}_{5}{ }^{2+}$ product ions $\left(\mathrm{b}_{5}{ }^{2+}>\mathrm{b}_{5}{ }^{+}\right.$for RVYIHAF and $\mathrm{b}_{5}{ }^{2+}<\mathrm{b}_{5}{ }^{+}$for RVYIHPF; Figures $5 \mathrm{C}$ and A).

\section{Controlling the Formation of Selective $\mathbf{b}^{2+}$ Product lons at Histidine Residues}

In support of the above model for complementary $\mathrm{b}^{+} / \mathrm{y}^{+}$or doubly charged $\mathrm{b}^{2+}$ product ion formation in doubly protonated histidine-containing peptides, MS/MS experiments were carried out on an angiotensin III analog where the histidine side chain t-nitrogen was alkylated. This was done to test the mechanism in Scheme 2 by blocking one of the two hydrogen transfers from the protonated histidine side chain to the departing C-terminal product (PF). Figure 6 shows the low-energy (ion trap) CID and SID of doubly protonated RVYIH*PF, where $\mathrm{H}^{*}$ stands for alkylated histidine. Clearly, the $\mathrm{b}_{5}{ }^{2+}$ product ion is the dominant sequence ion peak. Formation of the $\mathrm{H}^{*}$ immonium ion is a favorable process by SID (Figure 6B), although $\mathrm{b}_{5}{ }^{2+}$ is the most abundant sequence ion. No $\mathrm{b}_{5}{ }^{+}$or $\mathrm{y}_{2}{ }^{+}$product ions were observed at any of the activation energies investigated in contrast to the fragmentation behavior of doubly protonated RVYIHPF (compare Figures 1 with 6). This is presumably because there is no available proton for transfer from the side chain of the alkylated histidine in doubly protonated RVYIH*PF. In contrast, if the b ion formed were a typical protonated oxazolone intermediate, alkylation of the His-nitrogen should not 
influence subsequent $\mathrm{H}$-transfer. These SID and low-energy CID results also underscore the notion that protonated histidine is directly involved in formation of the $\mathrm{b}_{5}{ }^{+} / \mathrm{y}_{2}{ }^{+}$product ions in doubly protonated RVYIHPF and that histidine is a favorable site of protonation in this set of angiotensin peptides. The involvement of protonated histidine in the cleavage is also supported by the selective cleavage of $\Phi_{3} \mathrm{P}^{+} \mathrm{CH}_{2} \mathrm{C}(\mathrm{O})$-VYIHPF to form $\left[\Phi_{3} \mathrm{P}^{+} \mathrm{CH}_{2} \mathrm{C}(\mathrm{O})\right.$ $\mathrm{VYIH}+\mathrm{H}]^{2+}$ only when an added proton is present (a mimic of doubly protonated RVYIHPF, Figure 4B).

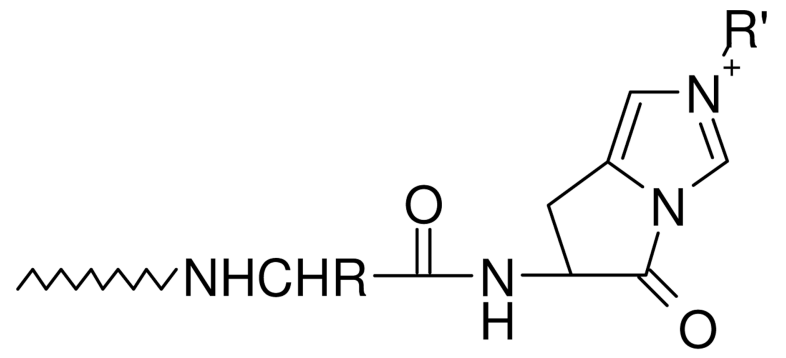

\section{Unique $b$ ion structure}

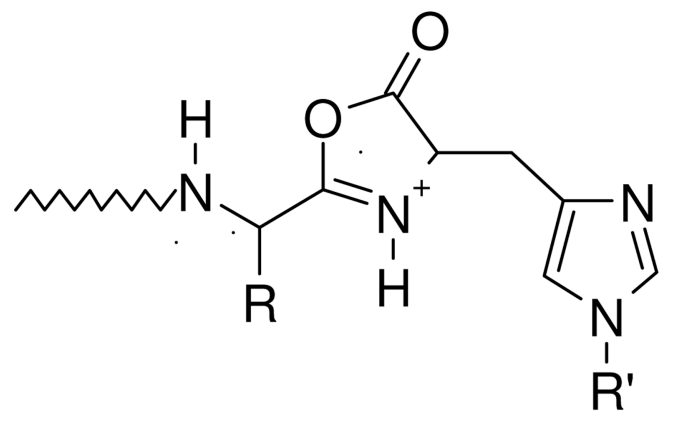

\section{Oxazolone $\mathrm{b}$ ion structure}

\section{Enhanced Cleavage One-Residue Away from Histidine}

It is of interest that in addition to the dominant $b_{5}{ }^{2+}$ product ions seen for doubly protonated RVYIHAF, $\mathrm{b}_{6}{ }^{2+}$ product ions are also abundant in the MS/MS spectrum of this peptide (Figure 5C). This is also true for doubly protonated RVYIHSarF (Figure 5B). Molecular modeling indicates that a very favorable interaction between protonated histidine and the carbonyl group of the AF peptide bond occurs in 40\% of 10000 structures of doubly protonated RVYIHAF. This dominant H-bond from the side chain of histidine to the XX peptide bond in HXX-containing peptides along with a subsequent proton transfer could lead to enhanced cleavage of the XX bond. It is of interest that while $\mathrm{b}_{6}{ }^{2+}$ product ions are of minor abundance from doubly protonated RVYIHPF, the molecular modeling indicates that the proton on the side chain of histidine comes within H-bonding distance ( $2.5 \AA)$ to the PF peptide carbonyl oxygen in $78 \%$ of structures sampled. Thus, although thermodynamically favorable, O-protonation at the PF peptide carbonyl oxygen does not lead to fragmentation in RVYIHPF because of the same stereo chemical factors which typically disfavor formation of an oxazolone structure C-terminal to a Pro residue. 


\section{Evidence for the Unique Histidine b Ion Structure}

In Sections II and IV and in Schemes 1 and 2, we propose that in the presence of a proton, selective cleavage $\mathrm{C}$-terminal to histidine leads to a unique bicyclic $\mathrm{b}$ ion. Recent ab initio calculations, which followed our initial unpublished data of the bicyclic His b ion structure, have shown that this unique $b$ ion structure ${ }^{40}$ is stabilized by the aromaticity of the imidazole ring. ${ }^{41}$ In order to probe further the structure of the histidine $b$ ion relative to other typical b ions (e.g., oxazolone or acylium ions) in protonated peptides, the doubly and singly charged product ions $\left(\mathrm{b}_{5}{ }^{2+}\right.$ and $\left.\mathrm{b}_{5}{ }^{+}\right)$were isolated in the ion trap and subjected to further fragmentation. In addition, resonance ejection experiments (Figure 7) were performed in the FTICR-MS to see if the $b_{5}{ }^{2+}$ and $b_{6}{ }^{2+}$ product ions of RVYIHAF are formed by independent mechanisms or if the $b_{5}{ }^{2+}$ ions are further fragments of the $b_{6}{ }^{2+}$ product ions. If the latter situation holds true, ejection of $\mathrm{b}_{6}{ }^{2+}$ product ions should result in no detectable $\mathrm{b}_{5}{ }^{2+}$ fragment ions assuming that multi step dissociation is not faster than ejection. It is clearly seen that upon ejection of the $\mathrm{b}_{6}{ }^{2+}$ product ions from doubly protonated RVYIHAF, $\mathrm{b}_{5}{ }^{2+}$ product ions still persist in the spectrum. Thus, within the limits of the timescale of the resonance ejection experiment, the $b_{5}{ }^{2+}$ ions are not further fragments of the $b_{6}{ }^{2+}$ product ions. Independent formation of these two doubly charged $b$ ions is consistent with our proposed model of how $\mathrm{b}_{\mathrm{n}}{ }^{2+}$ ions ( $\mathrm{n}=$ position of histidine) are formed immediately $\mathrm{C}$ terminal to histidine residues (Scheme 2).

To probe further the structures of the $b_{5}{ }^{2+}$ and $b_{6}{ }^{2+}$ from RVYIHAF, MS/MS/MS experiments were carried out. The trapping capabilities of the FTICR-MS and LCQ were exploited to isolate the $\mathrm{b}_{5}{ }^{2+}$ ions and then dissociate them further. The SORI-CID spectrum of the $\mathrm{b}_{5}{ }^{2+}$ product ions is shown in Figure 8A. The results demonstrate that the major fragments are $a_{5}{ }^{2+}$ ions, and formation of the (possibly complementary) $b_{4}$ and histidine immonium ions. Presuming $\mathrm{b}_{5}{ }^{2+}$ product ion generation as shown in Scheme 2, the loss of $\mathrm{CO}$ to give mainly $\mathrm{a}_{5}{ }^{2+}$ fragments is illustrated in Scheme 3.

Unlike MS/MS/MS of the $b_{5}{ }^{2+}$ product ions of RVYIHAF which leads to formation of $a_{5}{ }^{2+}$ fragment ions, the $b_{6}{ }^{2+}$ product ions of RVYIHAF fragment further to form exclusively $b_{5}{ }^{2+}$ fragment ions (Figure $8 \mathrm{~B}$ ). The lack of $\mathrm{CO}$ loss from $\mathrm{b}_{6}{ }^{2+}$ product ions suggests that these product ions do not have the same structure as the $b_{5}{ }^{2+}$ product ions shown in Schemes 2 and 3. Recently, cyclic oxazolone-like structures for generic $b$ ions produced in MS/MS of protonated peptides have been proposed. ${ }^{26,63-67} \mathrm{With}$ this in mind and considering the MS/MS/MS results for the $b_{6}{ }^{2+}$ products ions of RVYIHAF, Scheme 4 shows how a protonated oxazolone $\mathrm{b}_{6}{ }^{2+}$ product ion could be formed and subsequently dissociate to give $\mathrm{b}_{5}{ }^{2+}$ fragment ions. Following protonation on the alanyl peptide carbonyl oxygen (e.g. through a proton transfer step from the protonated side chain of histidine), nucleophilic attack by the carbonyl oxygen C-terminal to histidine occurs on the alanyl carbonyl carbon along with concomitant cleavage of the AF bond. This leads to formation of the protonated 5 -membered ring oxazolone-like $\mathrm{b}_{6}{ }^{2+}$ product ion and a neutral C-terminal fragment. The $\mathrm{b}_{5}{ }^{2+}$ fragment ion is formed from the $\mathrm{b}_{6}{ }^{2+}$ product ion by opening of the oxazolone 5membered ring structure through a nucleophilic attack by the histidine imino nitrogen on the electropositive oxazolone carbon. This produces $a b_{5}{ }^{2+}$ fragment ion whose local structure is identical to that shown in Schemes 2 and 3. Fourth stage MS experiments by low-energy 
CID of the $\mathrm{b}_{5}{ }^{2+}$ fragment ions produced from the $\mathrm{b}_{6}{ }^{2+}$ product ions indicated favorable loss of $\mathrm{CO}$ to give $\mathrm{a}_{5}{ }^{2+}$ fragment ions (supplementary figure 14). This is consistent with Scheme 3 above.

Additional evidence for a unique histidine $\mathrm{b}$ ion structure vis $\mathrm{a}$ vis a generic $\mathrm{b}$ ion was obtained by MS/MS/MS experiments of the $b_{5}{ }^{+}$product ions produced from RVYIHPF and RVYIFPF. Figure 9 shows the energy resolved fragmentation curves of the $\mathrm{b}_{5}{ }^{+}$product ions from doubly protonated RVYIFPF (Figure 9A) and RVYIHPF (Figure 9B). It is clearly evident that the two types of $\mathrm{b}_{5}{ }^{+}$product ions (FP cleavage and HP cleavage) further dissociate by accessing different low-energy fragmentation pathways resulting in different fractional abundances of $\mathrm{a}_{5}{ }^{+}, \mathrm{b}_{5}+*$ and $\mathrm{a}_{5}{ }^{+*}$ fragment ions. Whereas the $\mathrm{b}_{5}{ }^{+}$product ions from RVYIFPF lose CO readily to give $\mathrm{a}_{5}{ }^{+}$ions, $\mathrm{b}_{5}{ }^{+*}$ and $\mathrm{a}_{5}{ }^{+*}$ are also favorable products from the $b_{5}{ }^{+}$of RVYIHPF. This indicates that the stability of the $b_{5}{ }^{+}$product ions from RVYIFPF and RVYIHPF are different, likely as a consequence of different structures (i.e., typical oxazolone or acylium $b$ ions from RVYIFPF versus a unique histidine $b$ ion from RVYIHPF; Scheme 1).

\section{Conclusions}

In this work, the occurrence of selective cleavage at protonated histidine in the spectra of a systematically varied set of model peptides is supported by data obtained with three different activation methods that deposit different distributions of energy and that are associated with different time frames for dissociation. Strongly preferred cleavages at His-Zzz have been observed. The strong cleavage at His-Pro is in agreement with previous findings of similar dominant cleavages. ${ }^{56,57}$ A mechanism explaining the selective cleavage at histidine is proposed. These findings are of general interest and of importance because if high throughput MS-based peptide sequencing based on correlation analysis between experimental and theoretical spectra is to be reliable, predictive rules for peptide dissociation such as those presented here must be developed, tested and incorporated into algorithms.

Our proposed mechanism for selective cleavage at histidine is based on solvation of the ionizing proton on histidine by the carbonyl oxygen of the His-Xxx and His- $\mathrm{Xxx}-\mathrm{Xxx}$ bonds along with nucleophilic attack of the imino nitrogen on the electropositive peptide carbonyl carbon, to result in a unique histidine $\mathrm{b}$ product ion. This $\mathrm{b}$ ion incorporates the imidazole ring of histidine and $\mathrm{C}$-terminal end of the His-terminated peptide in a bicyclic structure. Evidence for this different $b$ ion structure at histidine (i.e., not acylium or oxazolone) is based on MS/MS/MS data for both singly and doubly charged $b$ ions. In this model for selective cleavage at histidine, a critical proton transfer step from the $\mathrm{N}$-terminal ionic species to the neutral C-terminal fragment during dissociation is important in giving rise to complementary $\mathrm{b}^{+} / \mathrm{y}^{+}$product ions (Scheme 2). Alternatively, lack of such a proton transfer step leads to formation of a doubly charged histidine $\mathrm{b}$ ion. Evidence for this comes from the MS/MS/MS spectra of doubly protonated precursor ions of RVYIH*PF, and RVYIHAF. Thus, although selective cleavage at histidine can be said to be independent of the residue Cterminal to histidine, the charge of the developing $b$ product ion is determined by the identity of the residue $\mathrm{C}$-terminal to histidine and by the ability of protonated histidine to transfer a proton to the $\mathrm{C}$-terminal leaving fragment. This implies that secondary interactions 
(e.g., hydrogen bonds or electrostatic interactions) that hold the complex together in the final proton transfer step must be important and that involvement of a proton in the vicinity of histidine to initiate selective cleavage is also clearly required.

\section{Supplementary Material}

Refer to Web version on PubMed Central for supplementary material.

\section{Acknowledgment}

This work was financially supported by a grant from the National Institutes of Health (GM RO15387 to V.H.W.), the National Science Foundation (CHE-9616711 to J.H.F), and a postdoctoral fellowship from the Fonds pour la Formation de Chercheurs et l'Aide à la Recherche (to G.T.). We wish to thank Chungang Gu for providing the AAHAA SID spectra and Dr. Árpad Somogyi for helpful discussions.

\section{References}

1. Anderson NL, Anderson NG. Electrophoresis. 1998; 19:1853-1861. [PubMed: 9740045]

2. Yates JR III. J. Mass Spectrom. 1998; 33:1-19. [PubMed: 9449829]

3. Eng JK, McCormack AL, Yates JR III. J. Am. Soc. Mass Spectrom. 1994; 5:976-989. [PubMed: 24226387]

4. Yates JR III, Eng JK, McCormack AL, Schieltz D. Anal. Chem. 1995; 67:1426-1436. [PubMed: 7741214]

5. Mann M, Wilm M. Anal. Chem. 1994; 66:4390-4399. [PubMed: 7847635]

6. Clauser, KR.; Baker, P.; Burlingame, AL. Portland, OR: 1996. p. 365

7. Perkins DN, Pappin DJC, Creasy DM, Cottrell JS. Electrophoresis. 1999; 20:3551-3567. [PubMed: 10612281]

8. Stahl DC, Swiderek KM, Davis MT, Lee TD. J. Am. Soc. Mass Spectrom. 1996; 7:532-540. [PubMed: 24203425]

9. McCormack AL, Schieltz DM, Goode B, Yang S, Barnes, Drubin D, Yates JR III. Anal. Chem. 1997; 69:767-776. [PubMed: 9043199]

10. Biemann, K.; McCloskey, JA., editors. New York: Academic Press; 1990. p. 455-479.

11. Biemann K. Methods Enzymol. 1990; 193:455-479. [PubMed: 2074832]

12. Roepstorff P, Fohlman J. Biomed. Mass Spectrom. 1984; 11:601-603. [PubMed: 6525415]

13. Papayannopoulos IA. Mass Spectrom. Rev. 1995; 14:49-73.

14. Alexander AJ, Thibault P, Boyd RK, Curtis JM, Rinehart KL. Int. J. Mass. Spectrom. Ion Processes. 1990; 98:107-134.

15. McCormack AL, Somogyi Á, Dongré AR, Wysocki VH. Anal. Chem. 1993; 65:2859-2872. [PubMed: 8250266]

16. Poulter L, Taylor LCE. Int. J. Mass. Spectrom. Ion Processes. 1989; 91:183-197.

17. Hunt DF, Henderson RA, Shabanowitz J, Sakaguchi K, Michel H, Sevilir N, Cox AL, Appella E, Engelhard VH. Science. 1992; 255:1261-1263. [PubMed: 1546328]

18. Ballard KD, Gaskell SJ. J. Am. Chem. Soc. 1992; 114:64-71.

19. Dongré AR, Somogyi Á, Wysocki VH. J. Mass Spectrom. 1996; 31:339-350. [PubMed: 8799282]

20. Carr SR, Cassady CJ. J. Mass Spectrom. 1997; 32:959-967. [PubMed: 9311149]

21. Dongré AR, Jones JL, Somogyi Á, Wysocki VH. J. Am. Chem. Soc. 1996; 118:8365-8374.

22. Summerfield SG, Whiting A, Gaskell SJ. Int. J. Mass. Spectrom. Ion Process. 1997; 162:149-161. 23. Qin J, Chait BT. J. Am. Chem. Soc. 1995; 117:5411-5412.

24. Tang X-J, Thibault P, Boyd RK. Anal. Chem. 1993; 65:2824-2834. [PubMed: 7504416]

25. Nair H, Somogyi Á, Wysocki VH. J. Mass Spectrom. 1996; 31:1141-1148. [PubMed: 8916423]

26. Vaisar T, Urban J. J. Mass Spectrom. 1998; 33:505-524. 
27. Downard KM, Biemann K. Int. J. Mass. Spectrom. Ion Processes. 1995; 148:191-202.

28. Dongré, AR.; Hayward, MJ.; Wysocki, VH. Atlanta, GA; 1995. p. 628

29. Wu QY, van Orden S, Cheng XH, Bakhtiar R, Smith RD. Anal. Chem. 1995; 67:2498-2509. [PubMed: 8686880]

30. Schnier PD, Price WD, Jockusch RA, Williams ER. J. Am. Chem. Soc. 1996; 118:7178-7189. [PubMed: 16525512]

31. Wyttenbach T, von Helden GV, Bowers MT. J. Am. Chem. Soc. 1996; 118:8355-8364.

32. Vachet RW, Asam MR, Glish GL. J. Am. Chem. Soc. 1996; 118:6252-6256.

33. Thorne GC, Ballard KD, Gaskell SJ. J. Am. Soc. Mass Spectrom. 1990; 1:249-257.

34. Tsaprailis G, Nair H, Somogyi Á, Wysocki VH, Zhong W, Futrell JH, Summerfield SG, Gaskell SJ. J. Am. Chem. Soc. 1999; 121:5142-5154.

35. Tsaprailis G, Somogyi A, Nikolaev E, Wysocki V. Int. J. Mass Spectrom. 2000; 195/196:467-479.

36. Yu W, Vath JE, Huberty MC, Martin SA. Anal. Chem. 1993; 65:3015-3023. [PubMed: 8256865]

37. Huang YY, Wysocki VH, Tabb DL, Yates JR. Int. J. Mass Spectrom. 2002; 219:233-244.

38. Stephenson J Jr. Cargile BJ, McLuckey SA. Rapid. Commun. Mass Spectrom. 1999; 13:20402048. [PubMed: 10510418]

39. Tabb DL, Smith LL, Breci LA, Wysocki VH, Lin D, Yates JRI. Anal. Chem. 2003; 75:1155-1163. [PubMed: 12641236]

40. Wysocki VH, Tsaprailis G, Smith LL, Breci LA. J. Mass Spectrom. 2000; 35:1399-1406. [PubMed: 11180630]

41. Farrugia JM, Taverner T, O’Hair RAJ. Int. J. Mass Spectrom. 2001; 209:99-112.

42. Atherton, E.; Sheppard, RC. Solid Phase Peptide Synthesis: A Practical Approach. Rickwood, D.; Hames, BD., editors. Oxford, UK: Oxford University Press; 1989.

43. Fletcher A, Jones J, Ramage W, Stachulski A. J. Chem. Soc. Perkin Trans. I. 1979:2261-2267.

44. Wysocki VH, Ding J-M, Jones JL, Callahan JH, King FL. J. Am. Soc. Mass Spectrom. 1992; 3:2732. [PubMed: 24242834]

45. Chowdhury SK, Katta V, Chait BF. Rapid Commun. Mass Spectrom. 1990; 4:81-87. [PubMed: 2134340]

46. Papac DI, Schey KL, Knapp DR. Anal. Chem. 1991; 63:1658-1660. [PubMed: 1952088]

47. Ulman A. Chem. Rev. 1996; 96:1533-1554. [PubMed: 11848802]

48. Marshall AG, Grosshans PB. Anal. Chem. 1991; 63:215A-229A.

49. Gauthier JW, Trautman TR, Jacobson DB. Anal. Chim. Acta. 1991; 246:211-225.

50. Senko MW, Speir JP, McLafferty FW. Anal. Chem. 1994; 66:2801-2808. [PubMed: 7978294]

51. Mohamadi F, Richards NGJ, Guida WC, Liskamp R, Lipton M, Caufield C, Chang G, Henderickson T, Still WC. J. Comput. Chem. 1990; 11:440-467.

52. Weiner S, Kollman P, Case D, Singh U, Ghio C, Alagona G, Profeta S, Weiner P. J. Am. Chem. Soc. 1984; 106:765-784.

53. Polak E, Ribiere G. Revue Française Inf. Rech. Oper. 1969; 16-R1:35-42.

54. Meot-Ner M, Dongré AR, Somogyi Á, Wysocki VH. Rapid Commun. Mass Spectrom. 1995; 9:829-836. [PubMed: 7655076]

55. Gordon D, Woods M. Rapid Commun. Mass Spectrom. 1993; 7:215-218.

56. Hu P, Loo JA. J. Am. Chem. Soc. 1995; 117:11314-11319.

57. Adams J, Strobel FH, Reiter A, Sullards MC. J. Am. Soc. Mass Spectrom. 1996; 7:30-41. [PubMed: 24202792]

58. Sullards M, Reiter J. J. Am. Soc. Mass Spectrom. 2000; 11:40-53. [PubMed: 10631663]

59. Tang X-J, Boyd RK. Rapid Commun. Mass Spectrom. 1992; 6:651-657. [PubMed: 1467549]

60. Campbell S, Beauchamp JL, Rempe M, Lichtenberger DL. Int. J. Mass. Spec. Ion Processes. 1992; 117:83-99.

61. Wu Z, Fenselau C. Rapid Commun. Mass Spectrom. 1992; 6:403-405.

62. Starrett AM, DiDonato GC. Rapid Commun. Mass Spectrom. 1993; 7:12-15. 
63. Nold MJ, Wesdemiotis C, Yalcin T, Harrison AG. Int. J. Mass. Spectrom. Ion Processes. 1997; 164:137-153.

64. Yalcin T, Khouw C, Csizmadia IG, Peterson MR, Harrison AG. J. Am. Soc. Mass Spectrom. 1995; 6:1165-1174. [PubMed: 24214067]

65. Yalcin T, Csizmadia IG, Peterson MR, Harrison AG. J. Am. Soc. Mass Spectrom. 1996; 7:233242. [PubMed: 24203294]

66. Arnott, D.; Kottmeir, D.; Yates, JR., III; Shabanowitz, J.; Hunt, DF. Chicago, IL: 1994. p. 470

67. Summerfield SG, Bolgar MS, Gaskell SJ. J. Mass Spectrom. 1997; 32:225-231.

68. Johnson RS, Martin SA, Biemann K. Int. J. Mass. Spectrom. Ion Processes. 1988; 86:137-154.

69. Biemann K, Martin SA. Mass. Spectrom. Rev. 1987; 6:1-76.

70. Downard KM, Biemenn K. J. Am. Soc. Mass Spectrom. 1994; 5:966-975. [PubMed: 24226386]

71. Ishikawa K, Nishimura T, Koga Y, Niwa Y. Rapid Commun. Mass Spectrom. 1994; 8:933-938. [PubMed: 7696702]

72. Kiryushkin AA, Fales HM, Axenrod T, Gilbert EJ, Milne GW. Org. Mass Spectrom. 1971; 5:19_ 31.

73. Schlosser A, Lehmann WD. J. Mass Spectrom. 2000; 35:1382-1390. [PubMed: 11180628]

74. Csonka IP, Paizs B, Lendvay G, Suhai S. Rapid Commun. Mass Spectrom. 2000; 14:417-431. [PubMed: 10717650]

75. Burlet O, Orkiszewski RS, Ballard KD, Gaskell SJ. Rapid Commun. Mass Spectrom. 1992; 6:658662. [PubMed: 1467550]

76. Burlingame AL, Boyd RK, Gaskell SJ. Anal. Chem. 1996; 68:599R-651R.

77. Summerfield SG, Cox KA, Gaskell SJ. J. Am. Soc. Mass Spectrom. 1997; 8:25-31.

78. Loo JA, Edmonds CG, Smith RD. Anal. Chem. 1993; 65:425-438. [PubMed: 8382455]

79. Vaisar T, Urban J. J. Mass Spectrom. 1996; 31:1185-1187. [PubMed: 8916427]

80. Chowdhury SK, Katta V, Chait BT. J. Am. Chem. Soc. 1990; 112:9012-9013.

81. Guevremont R, Siu KWM, LeBlanc JCY, Berman SS. J. Am. Soc. Mass Spectrom. 1992; 3:216224. [PubMed: 24242944]

82. Nold MJ, Cerda B, Wesdemiotis C. J. Am. Soc. Mass Spectrom. 1999; 10:1-8. [PubMed: 9888180]

83. Cordero MM, Houser JJ, Wesdemiotis C. Anal. Chem. 1993; 65:1594-1601. [PubMed: 8328675]

84. Cordero M, Wesdemiotis C. Org. Mass Spectrom. 1994; 29:382-390.

85. Mueller DR, Eckersley M, Richter WJ. Org. Mass Spectrom. 1988:217-222. 


\section{R V Y I H P F}

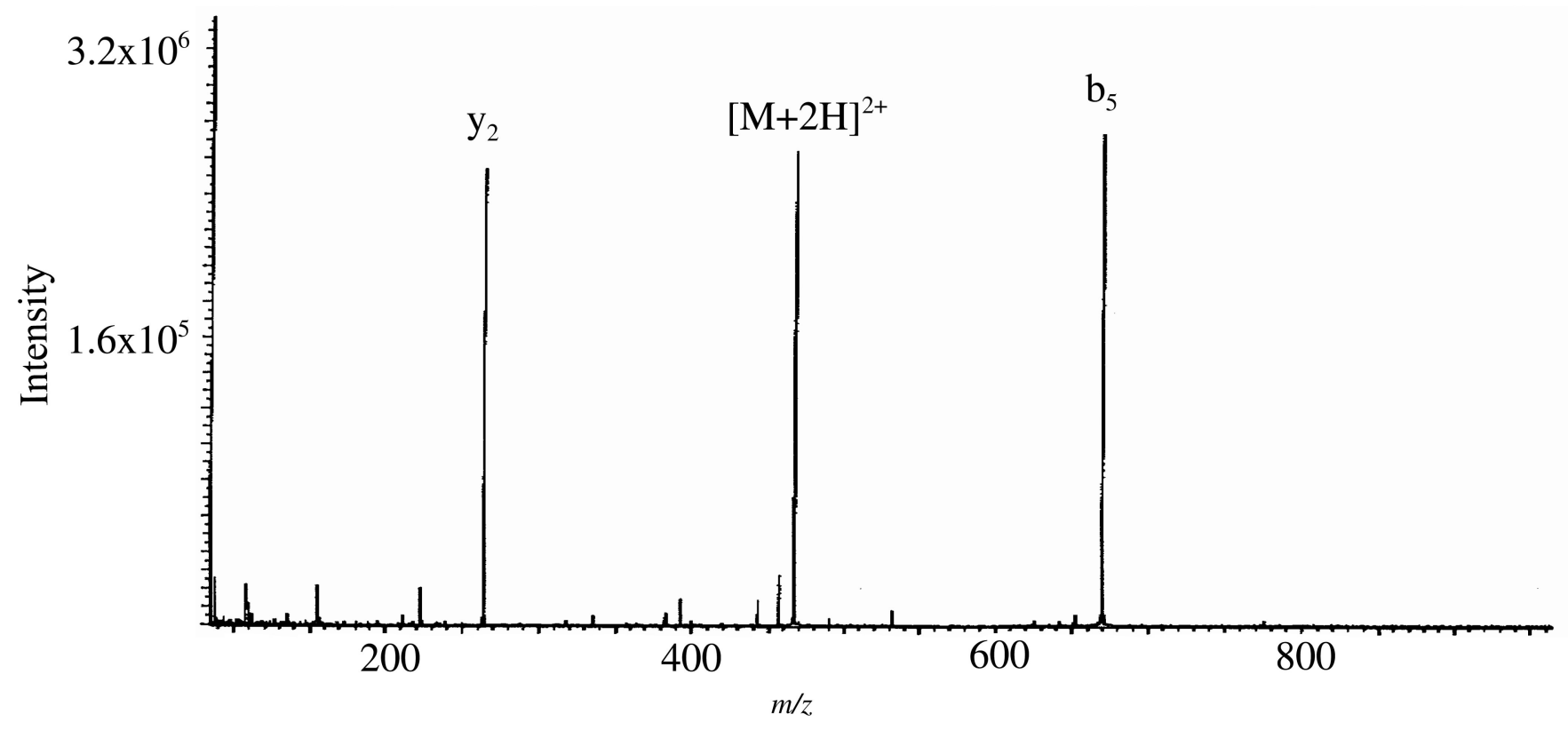

Figure 1.

MS/MS spectrum of doubly protonated RVYIHPF obtained by sustained off-resonance irradiation at an excitation energy of $6 \mathrm{eV}$; Electrospray ionization. 


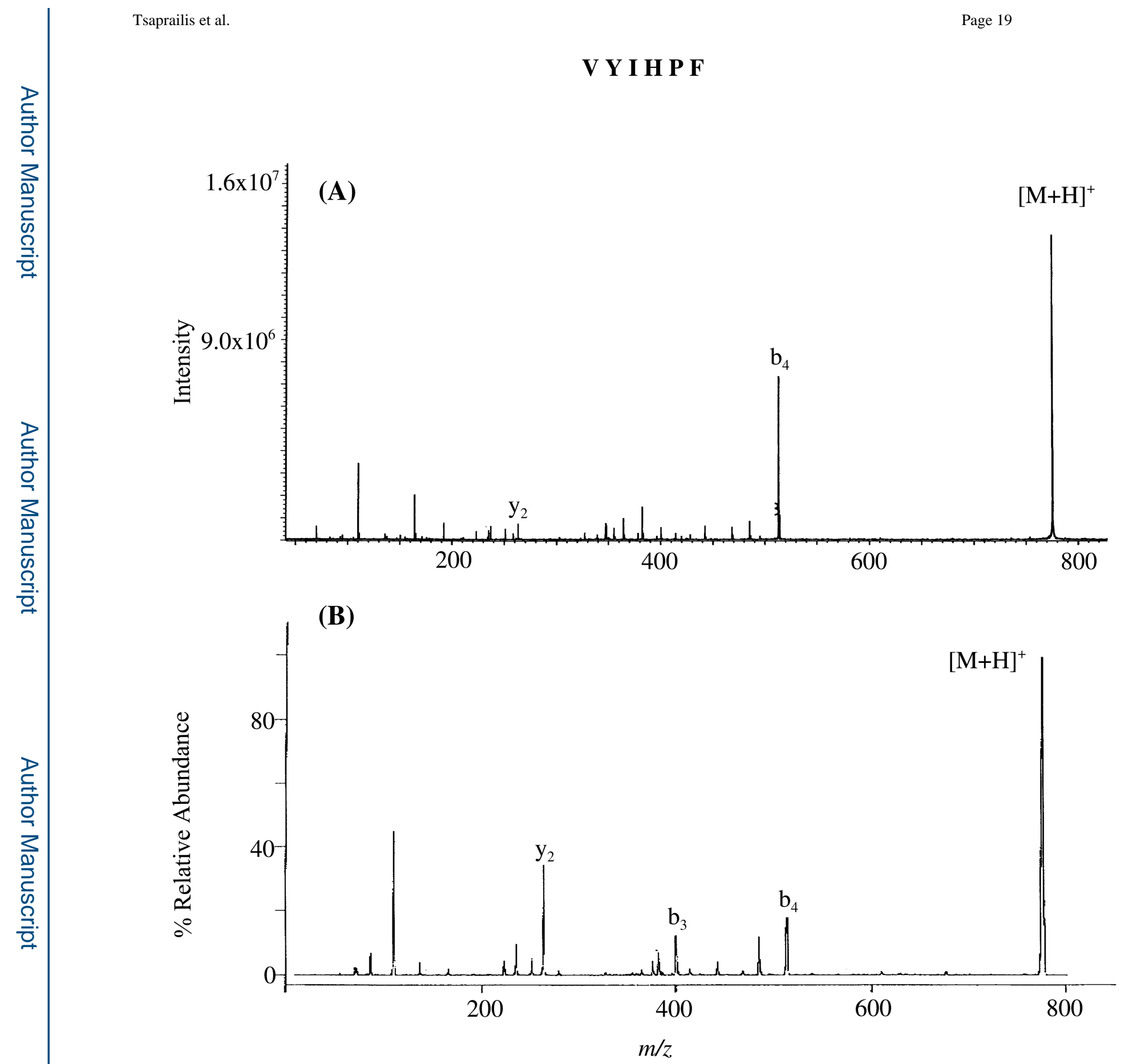

Figure 2.

MS/MS spectrum of singly protonated VYIHPF obtained by (A) sustained off-resonance irradiation at an excitation energy of $19 \mathrm{eV}$ and (B) SID at a collision energy of $35 \mathrm{eV}$ on a 2-(perfluorooctyl)ethanethiolate $\left[\mathrm{CF}_{3}\left(\mathrm{CF}_{2}\right)_{7} \mathrm{CH}_{2} \mathrm{CH}_{2} \mathrm{~S}-\mathrm{Au}\right]$ monolayer surface; Electrospray ionization. 


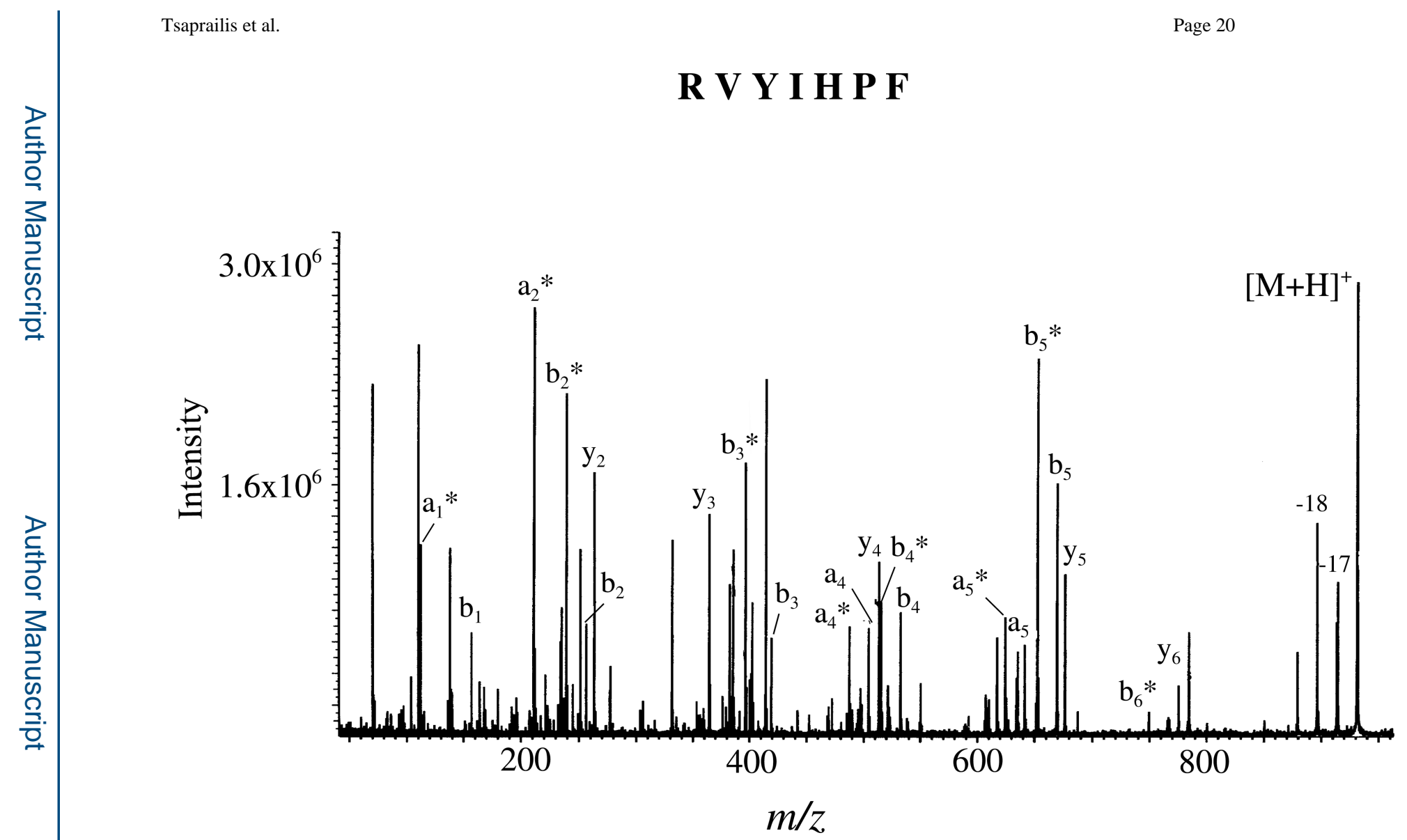

Figure 3.

MS/MS spectrum of singly protonated RVYIHPF obtained by sustained off-resonance irradiation at an excitation energy of $34 \mathrm{eV}$; Electrospray ionization. 


\section{$\Phi_{3} \mathbf{P}^{+} \mathrm{CH}_{2} \mathrm{C}(\mathrm{O})-\mathrm{V}$ Y I H P F}

100

(A)

$\begin{array}{ll}0 & 80 \\ 0 & \\ \frac{0}{0} & \\ \vdots & \\ 0 & 60 \\ 0 & \\ \frac{0}{0} & \\ \frac{0}{0} & 40 \\ \frac{0}{0} & \end{array}$

20

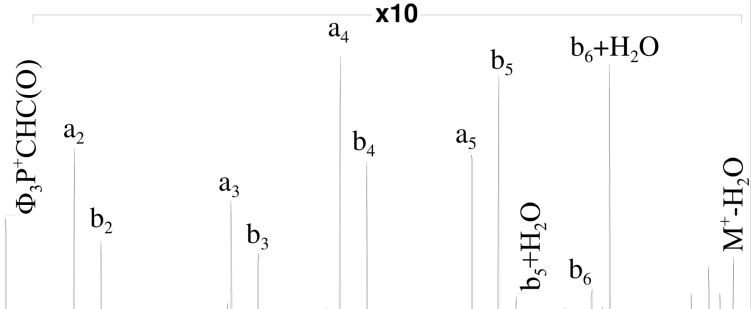

0

$\begin{array}{llllllllllll}400 & 500 & 600 & 700 & 800 & 900 & 1000 & 1100 & 1200 & 1300 & 1400 & 1500\end{array}$

$\mathrm{m} / \mathrm{z}$

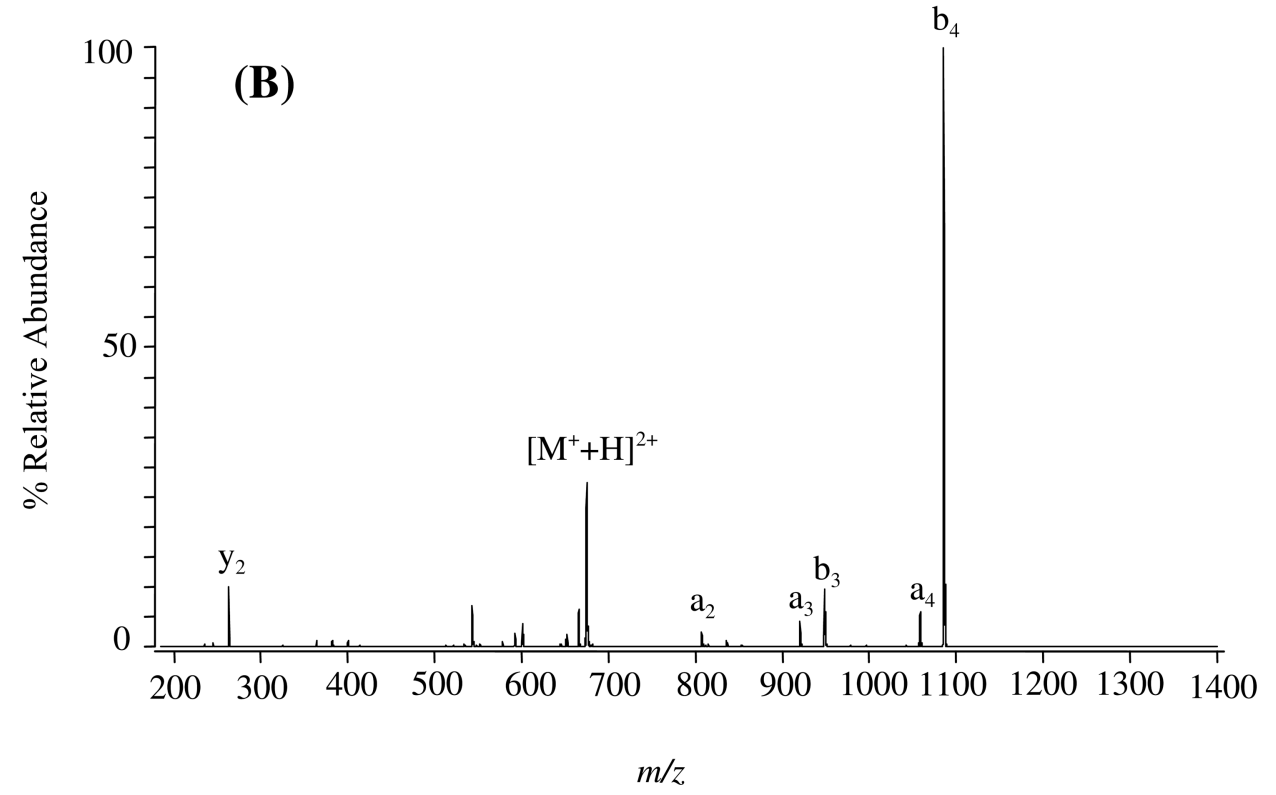

Figure 4.

Low-energy CID spectrum of (A) $\Phi_{3} \mathrm{P}^{+} \mathrm{CH}_{2} \mathrm{C}(\mathrm{O})$-VYIHPF at $30 \%$ relative collision energy, and $(\mathbf{B})\left[\Phi_{3} \mathrm{P}^{+} \mathrm{CH}_{2} \mathrm{C}(\mathrm{O})-\mathrm{VYIHPF}+\mathrm{H}\right]^{2+}$ at $22 \%$ relative collision energy; Electrospray ionization. 

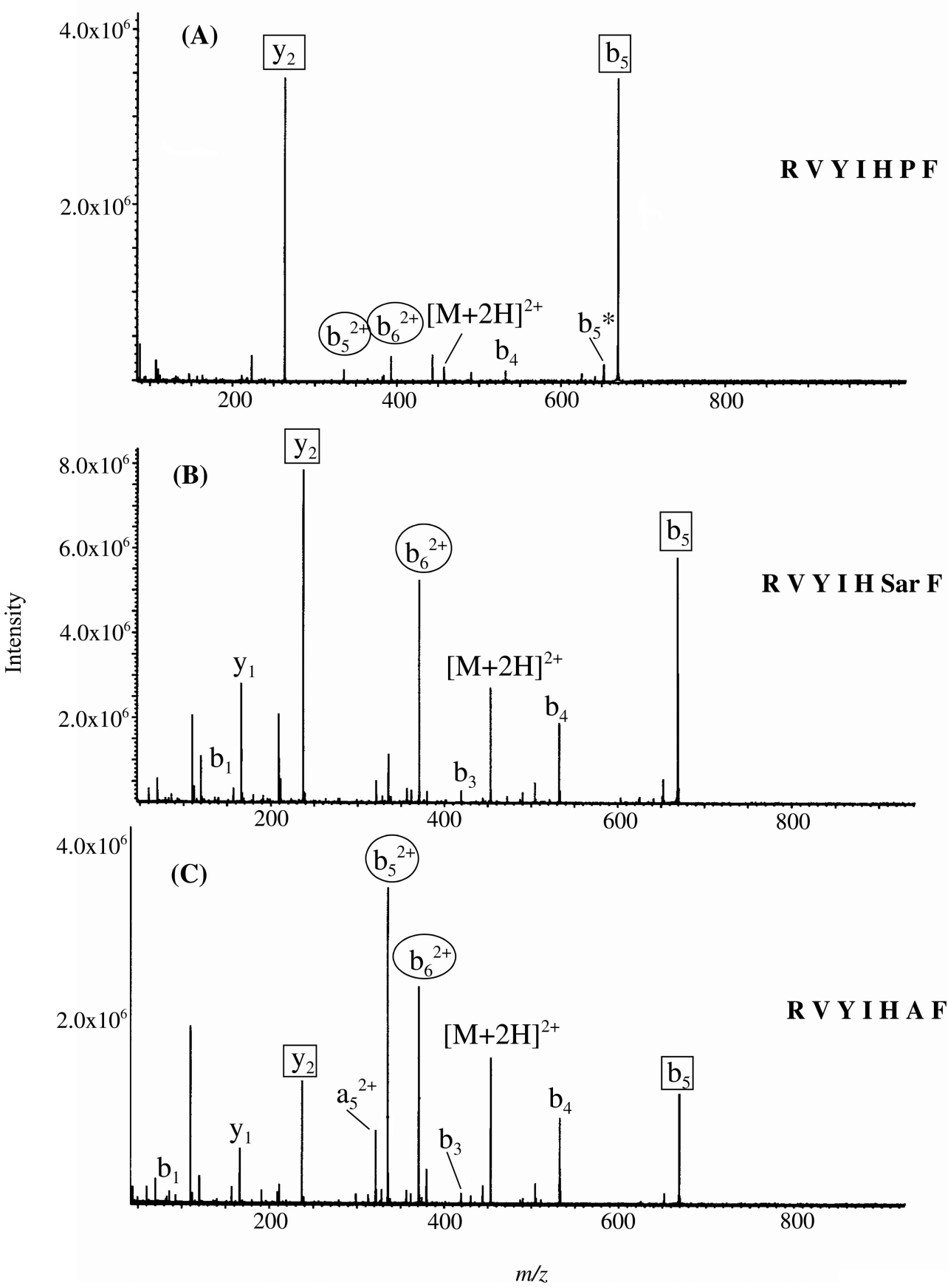

Figure 5.

SORI-CID spectra of doubly protonated (A) RVYIHPF, (B) RVYIHSarF and (C)

RVYIHAF at an excitation energy of $9 \mathrm{eV}$; Electrospray ionization. Fragments of interested are circled as squares (singly charged fragments) and as ovals (doubly charged fragments). 


\section{R V Y I H*P F}
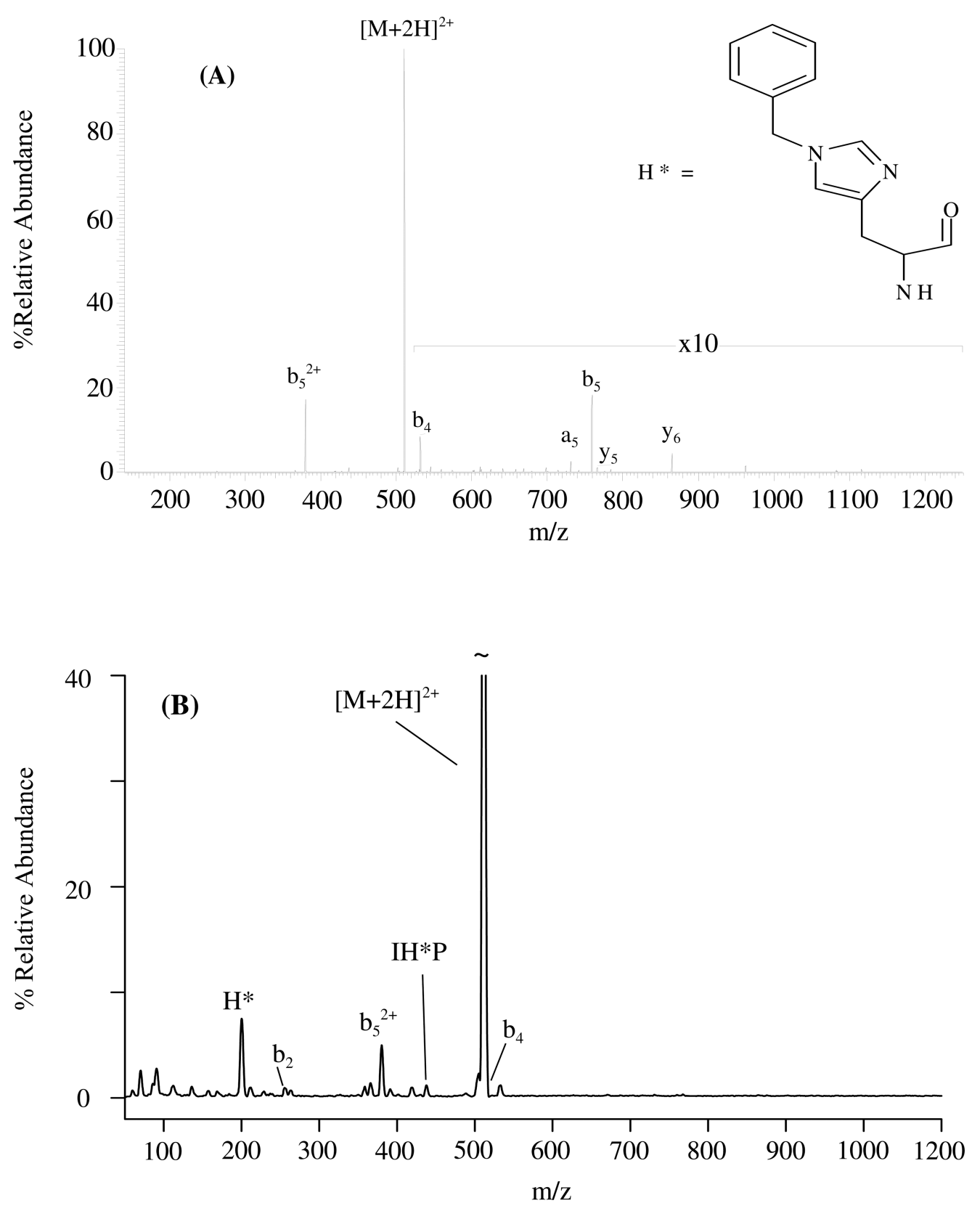

Figure 6.

Dominant $\mathrm{b}_{5}{ }^{2+}$ product ion formation in RVYIH*PF by (A) low-energy CID at a $18.2 \%$ relative collision energy and (B) SID at a collision energy of $30 \mathrm{eV}$ on a 2(perfluorodecyl)ethanethiolate $\left[\mathrm{CF}_{3}\left(\mathrm{CF}_{2}\right)_{9} \mathrm{CH}_{2} \mathrm{CH}_{2} \mathrm{~S}-\mathrm{Au}\right]$ monolayer surface; Electrospray ionization. 


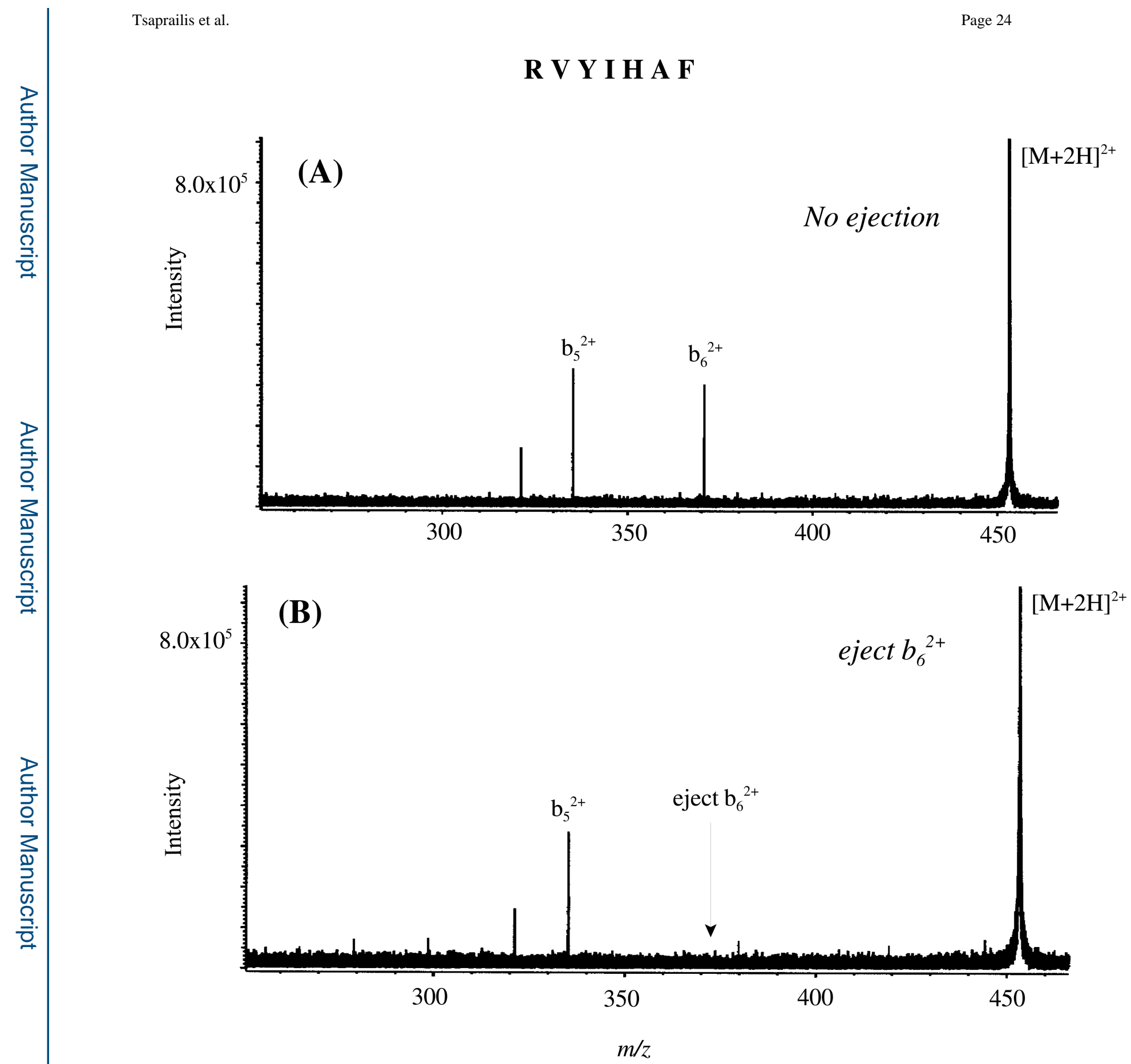

Figure 7.

On-resonance CID spectrum of doubly protonated RVYIHAF with (A) no resonance ejection and (B) with resonance ejection of the $\mathrm{b}_{6}{ }^{2+}$ product ion; Electrospray ionization. 

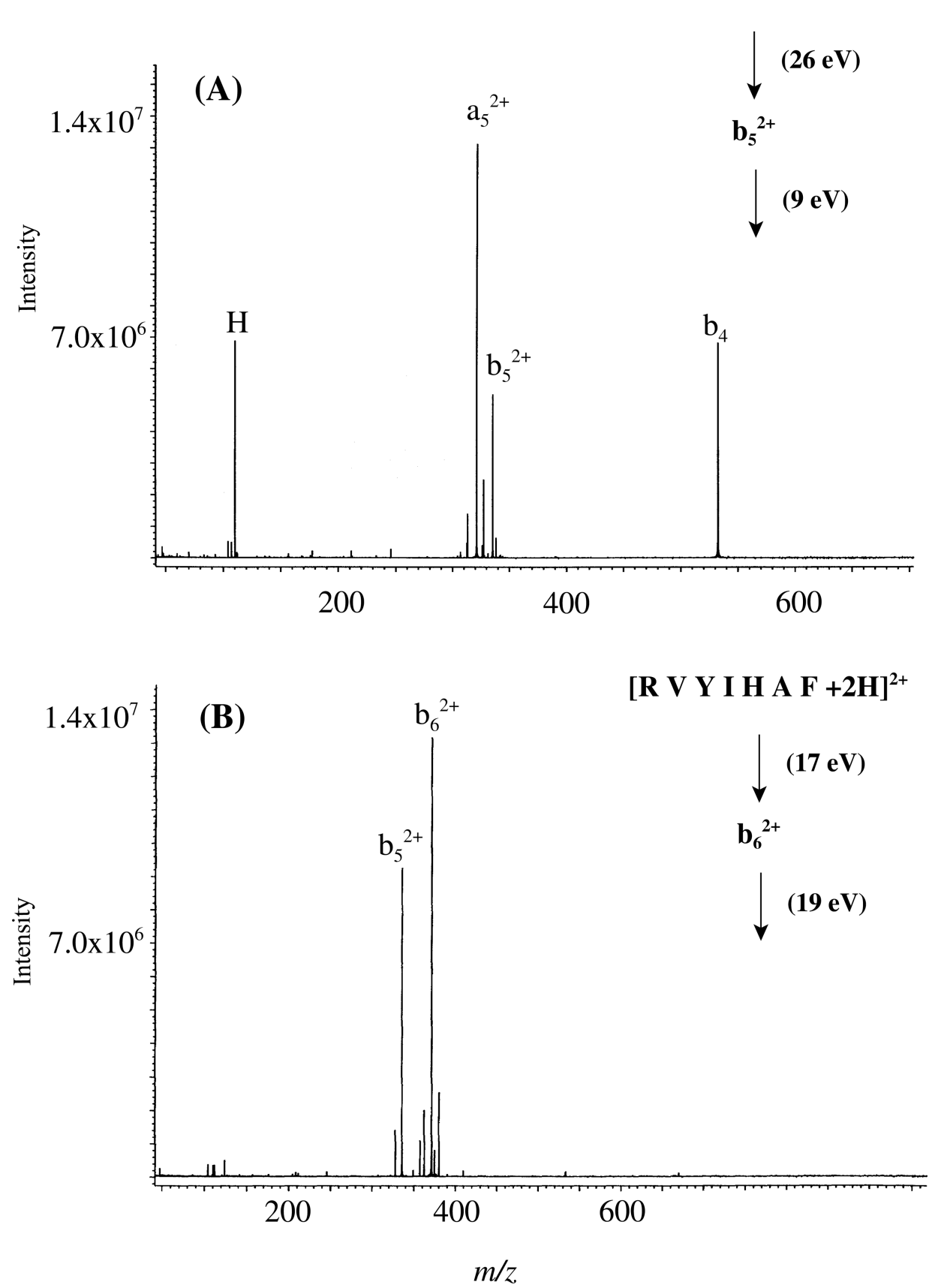

Figure 8.

(A) $9-\mathrm{eV}$ MS/MS/MS SORI-CID spectrum of the selected $b_{5}{ }^{2+}$ product ion of doubly protonated RVYIHAF at $26 \mathrm{eV}$ collision and (B) 19-eV MS/MS/MS SORI-CID spectrum of the selected $\mathrm{b}_{6}{ }^{2+}$ product ion of doubly protonated RVYIHAF at $17 \mathrm{eV}$ collision;

Electrospray ionization. 


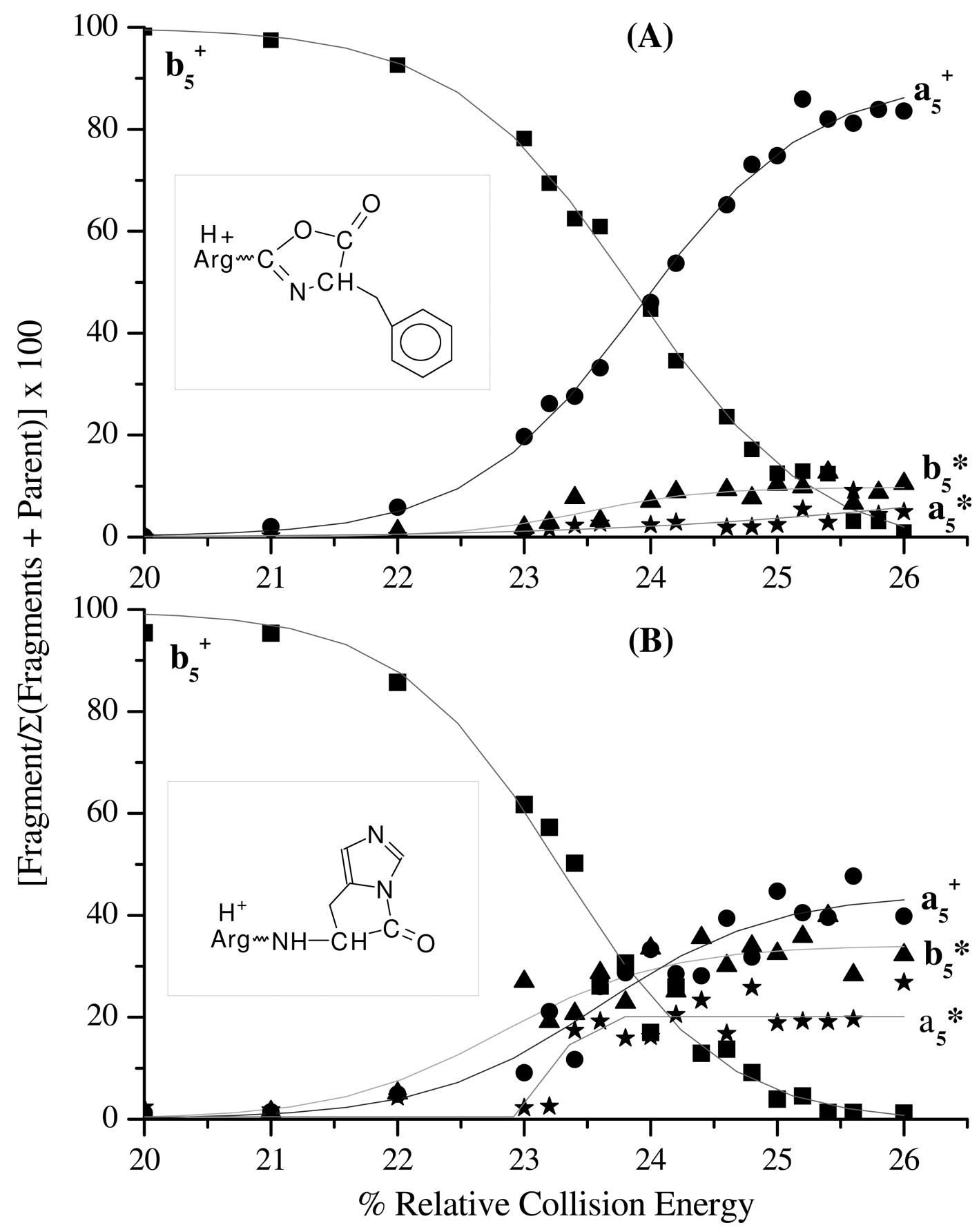

Figure 9.

Low-energy CID resolved fragmentation curves upon further dissociation of the $\mathrm{b}_{5}{ }^{+}$product ions ( $\square$ ) from (A) doubly protonated RVYIFPF and (B) doubly protonated RVYIHPF. The fragment ions plotted are the $\mathrm{a}_{5}{ }^{+}$ions $(\boldsymbol{O}), \mathrm{b}_{5}{ }^{*}(\boldsymbol{\Delta})$, and $\mathrm{a}_{5}{ }^{*}(\star)$ ions. The inserts show the structures of a generic $\mathrm{b}$ ion (oxazolone; part $\mathrm{A}$ ) and the proposed $\mathrm{b}$ ion at histidine. 

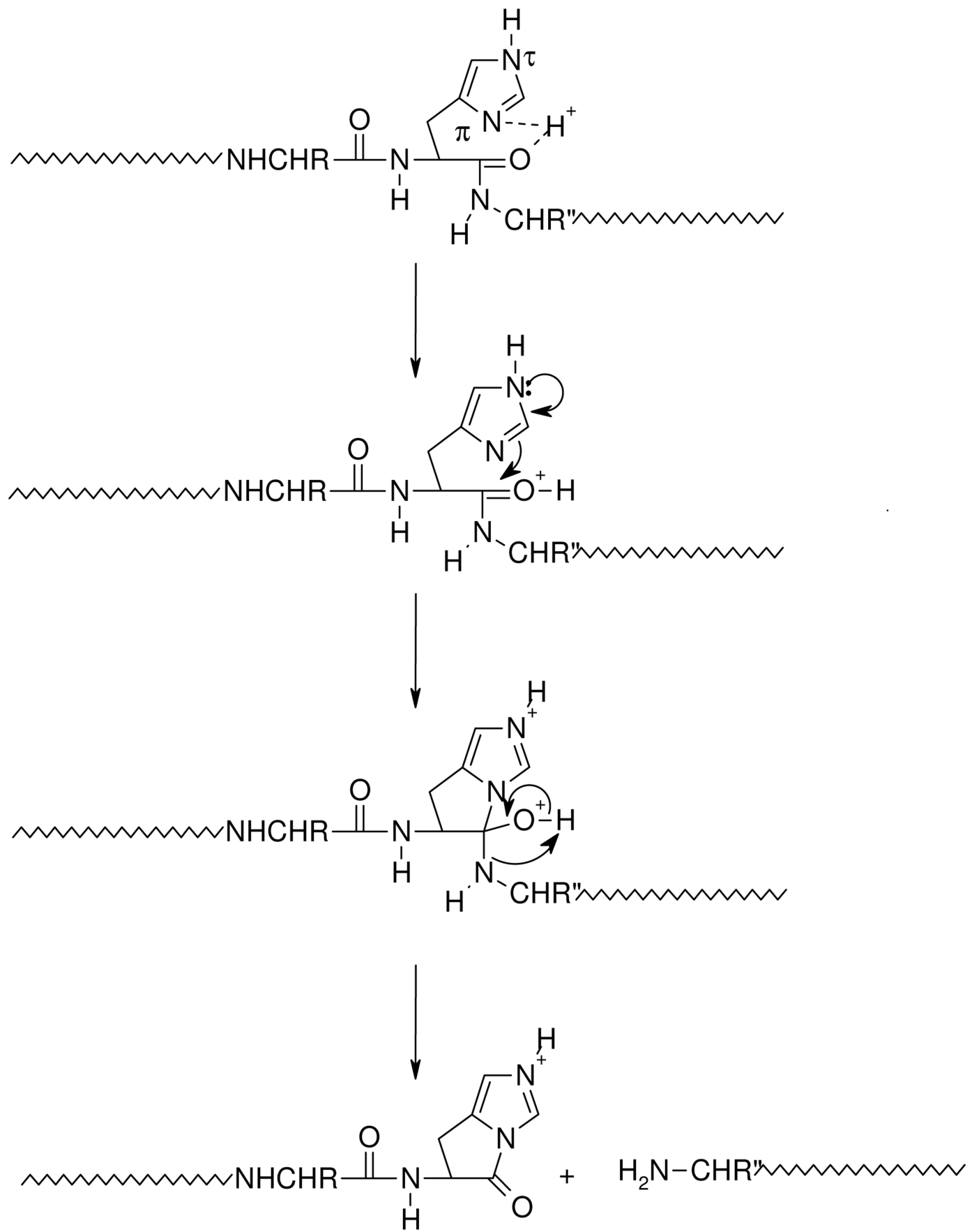

Scheme 1.

Proposed mechanism for the formation of the histidine $b$ ion. Transfer of the ionizing proton by protonated histidine to the peptide oxygen renders the carbonyl carbon electropositive. Nucleophilic attack by the imino nitrogen of histidine on the electropositive carbonyl carbon along with $\mathrm{N}$-protonation leads to breaking of the peptide bond and the fused bicyclic ring $\mathrm{b}$ ion structure. The C-terminal leaving piece is neutral. 
$\mathrm{H}_{2} \mathrm{~N}$

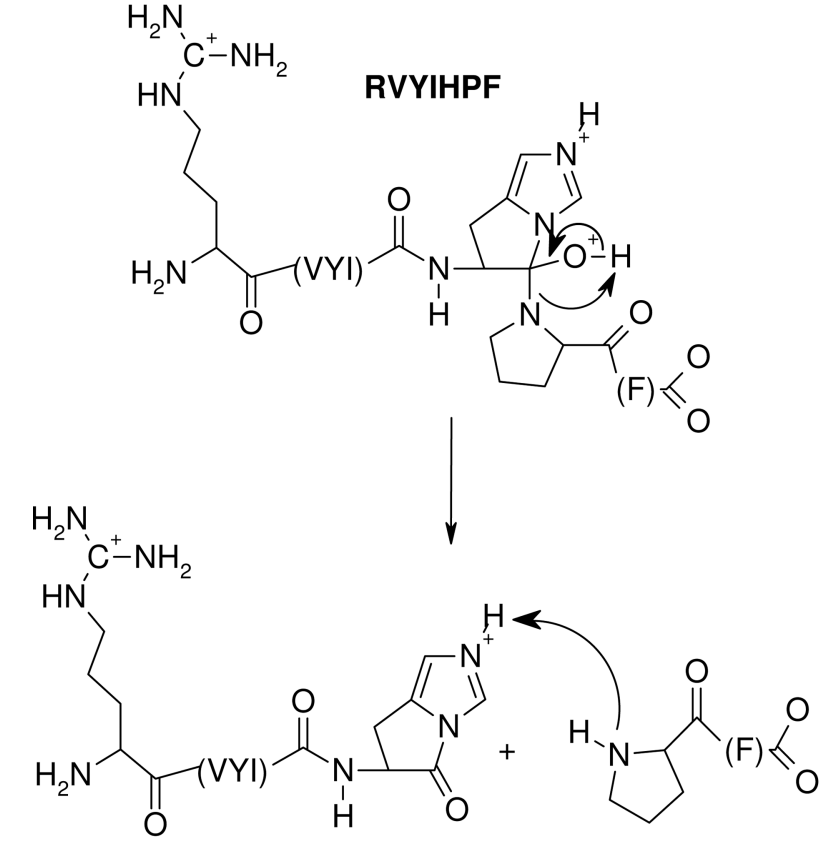

$\mathrm{H}_{2} \mathrm{~N}$

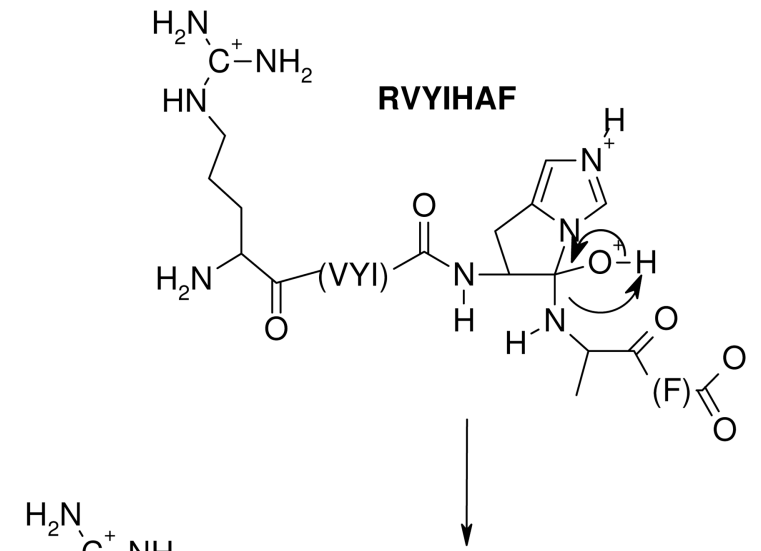

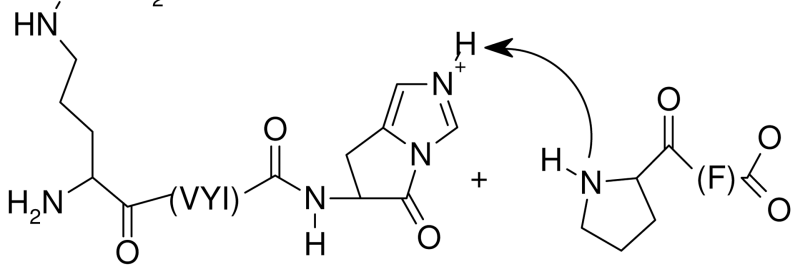<smiles>C[C@H](N)NCCCC(N)C(=O)NCC(=O)NC1Cc2c[nH+]cn2C1=O</smiles><smiles>CC(N)C(=O)[I-]C(=O)O</smiles><smiles>NC(CCCN[14C](N)N)C(=O)NNC(=O)NC1Cc2cncn2C1=O</smiles><smiles>[Y6][I-]C(=O)OC(=O)C1CCC[NH2+]1</smiles><smiles></smiles><smiles>CC(N)C(=O)[I-]C(=O)O</smiles>

Neutral Fragment

Scheme 2.

Proposed mechanism for the formation of complementary $\mathrm{b}^{+} / \mathrm{y}^{+}$and $\mathrm{b}^{2+}$ product ions at histidine from doubly protonated peptides. Following formation of an ion neutral complex as in Scheme 1, a proton transfer step to the C-terminal leaving piece results in the complementary $\mathrm{b}_{5}{ }^{+} / \mathrm{y}_{2}{ }^{+}$ions in RVYIHPF (left side). No proton transfer step leaves both charges on the N-terminal piece resulting in a $b_{5}{ }^{2+}$ product ion in RVYIHAF (right side). 
<smiles>N=C(N)N</smiles><smiles>CN</smiles><smiles>CCCCCC</smiles><smiles>CCC(N)C(N)=O</smiles>

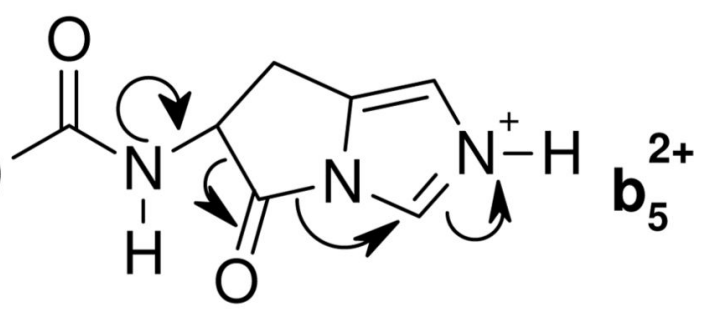<smiles>CNC(N)=[NH2+]</smiles>

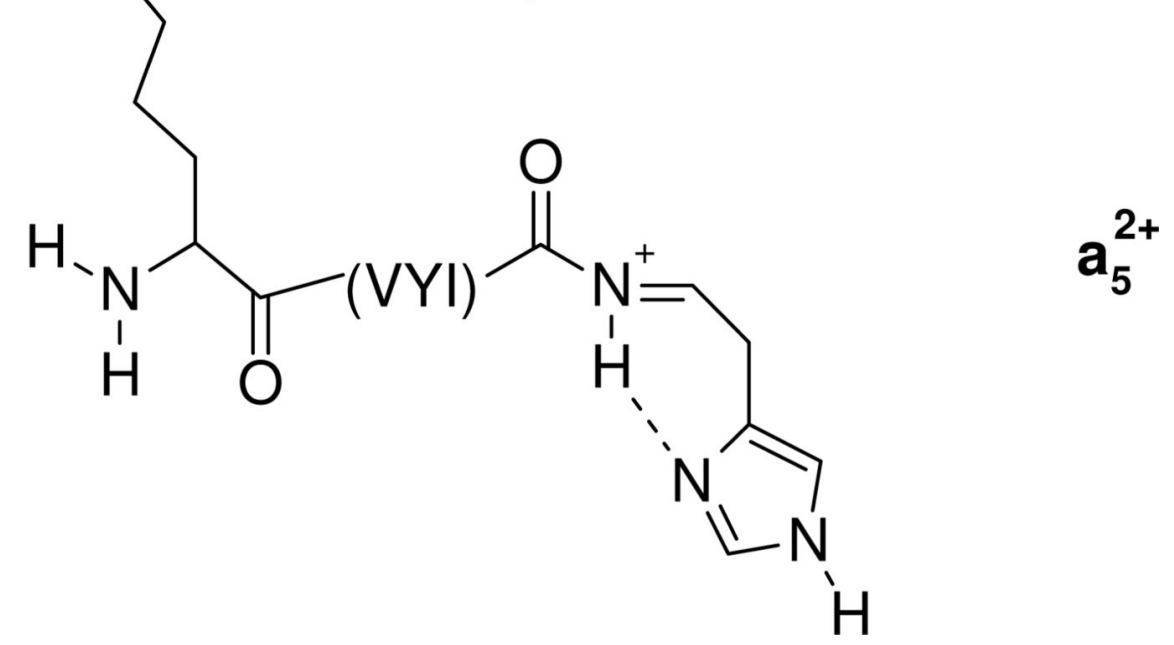

Scheme 3.

Proposed mechanism for the fragmentation of $b_{5}{ }^{2+}$ product ions from doubly protonated RVYIHAF precursor ions. 
$\mathrm{H}_{2} \mathrm{~N}$

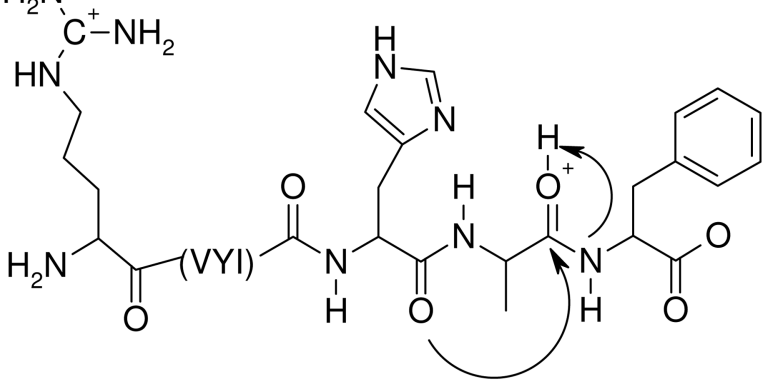

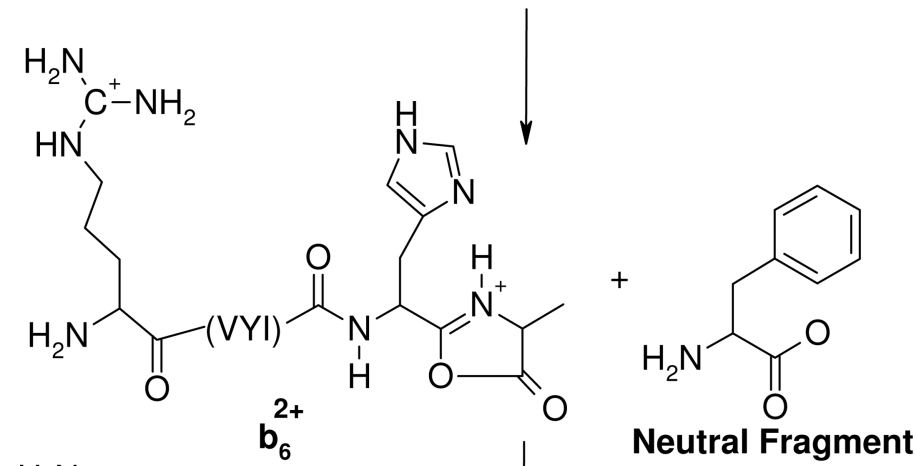

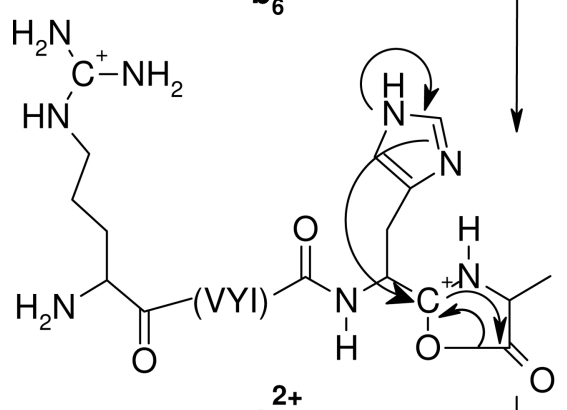

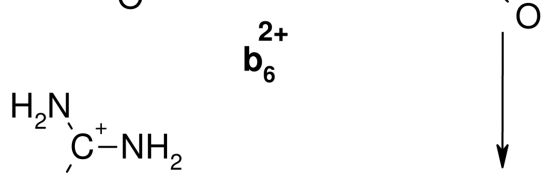<smiles>CC1NC1=O</smiles>

Scheme 4.

Proposed mechanism for the fragmentation of $b_{6}{ }^{2+}$ product ions of doubly protonated RVYIHAF. Following cleavage of the Ala-Phe bond to produce an oxazolone $\mathrm{b}_{6}{ }^{2+}$ product ion, nucleophilic attack by the histidine imino nitrogen on the electropositive carbon of the oxazolone occurs. This results in $a b_{5}{ }^{2+}$ fragment ion with same structure as the $b_{5}{ }^{2+}$ ions shown in Scheme 2. 